\title{
Age-Related Changes in D-Aspartate Oxidase Promoter Methylation Control Extracellular D-Aspartate Levels and Prevent Precocious Cell Death during Brain Aging
}

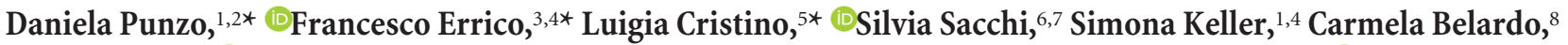 \\ Livio Luongo, ${ }^{8}$-Tommaso Nuzzo, ${ }^{2,3}$ Roberta Imperatore, ${ }^{5}$ Ermanno Florio, ${ }^{1,4}$ Vito De Novellis, ${ }^{8}$ COrnella Affinito, ${ }^{1,4}$ \\ @Sara Migliarini, ${ }^{9}$ @Giacomo Maddaloni, ${ }^{9}$ Maria Josè Sisalli, ${ }^{1}$ @Massimo Pasqualetti, ${ }^{9,10}$ @Loredano Pollegioni, ${ }^{6,7}$ \\ Sabatino Maione, ${ }^{8}$ Lorenzo Chiariotti, ${ }^{1,4}$ and Alessandro Usiello ${ }^{2,3}$ \\ ${ }^{1}$ Istituto di Endocrinologia ed Oncologia Sperimentale, Consiglio Nazionale delle Ricerche (CNR), 80131 Naples, Italy, ${ }^{2}$ Department of Environmental, \\ Biological and Pharmaceutical Sciences and Technologies, Second University of Naples, 81100 Caserta, Italy, ${ }^{3}$ Laboratory of Behavioural Neuroscience, \\ Ceinge Biotecnologie Avanzate, 80145 Naples, Italy, ${ }^{4}$ Department of Molecular Medicine and Medical Biotechnology, University of Naples Federico II, 80131 \\ Naples, Italy, ${ }^{5}$ Institute of Biomolecular Chemistry, CNR, 80078 Pozzuoli, Italy, ${ }^{6}$ Department of Biotechnology and Life Sciences, University of Insubria, \\ 21100 Varese, Italy, ${ }^{7}$ Protein Factory Research Center, Politecnico di Milano and University of Insubria, 20133 Milan, Italy, ${ }^{8}$ Department of Experimental \\ Medicine, Section of Pharmacology, Second University of Naples, 80138 Naples, Italy, ${ }^{9}$ Department of Biology, Unit of Cell and Developmental Biology, \\ University of Pisa, 56126 Pisa, Italy, and ${ }^{10}$ Center for Neuroscience and Cognitive Systems, Istituto Italiano di Tecnologia, 38068 Rovereto, Italy
}

The endogenous NMDA receptor (NMDAR) agonist D-aspartate occurs transiently in the mammalian brain because it is abundant during embryonic and perinatal phases before drastically decreasing during adulthood. It is well established that postnatal reduction of cerebral D-aspartate levels is due to the concomitant onset of D-aspartate oxidase (DD0) activity, a flavoenzyme that selectively degrades bicarboxylic $\mathrm{D}$-amino acids. In the present work, we show that $\mathrm{D}$-aspartate content in the mouse brain drastically decreases after birth, whereas $D$ do mRNA levels concomitantly increase. Interestingly, postnatal $D d o$ gene expression is paralleled by progressive demethylation within its putative promoter region. Consistent with an epigenetic control on Ddo expression, treatment with the DNA-demethylating agent, azacitidine, causes increased mRNA levels in embryonic cortical neurons. To indirectly evaluate the effect of a putative persistent $D d o$ gene hypermethylation in the brain, we used $D d o$ knock-out mice $\left(D d o^{-l-}\right)$, which show constitutively suppressed $D d o$ expression. In these mice, we found for the first time substantially increased extracellular content of D-aspartate in the brain. In line with detrimental effects produced by NMDAR overstimulation, persistent elevation of D-aspartate levels in $D d o^{-l-}$ brains is associated with appearance of dystrophic microglia, precocious caspase-3 activation, and cell death in cortical pyramidal neurons and dopaminergic neurons of the substantia nigra pars compacta. This evidence, along with the early accumulation of lipufuscin granules in $D d o^{-1-}$ brains, highlights an unexpected importance of $D d o$ demethylation in preventing neurodegenerative processes produced by nonphysiological extracellular levels of free D-aspartate.

Key words: aging; D-amino acids; DNA methylation; neurodegeneration; NMDA receptor

Significance Statement

The enzyme D-aspartate oxidase (DDO) catalyzes the degradation of the NMDA receptor agonist, D-aspartate. In the brain, DD0 is expressed only during postnatal life, thus reducing the embryonic storage of D-aspartate and keeping this D-amino acid at low levels during adulthood. Although the presence of DDO in mammals is long established, its biological role in the brain and the mechanism regulating its expression are still unclear. Here, we found that $D d o$ promoter demethylation enables the postnatal expression of $D d o$. Moreover, persistent suppression of $D d o$ expression leads to persistent spillover of extracellular D-aspartate and produces precocious cell death in the mouse brain, thus suggesting a key role for DDO in preventing early neurodegeneration triggered by excessive NMDA receptor stimulation. 


\section{Introduction}

Since the first discovery by Sir Hans Krebs in 1935, the presence of flavoproteins responsible for D-amino acids' deamination (Krebs, 1935; Still and Buell, 1949) is well known in mammals. In particular, D-aspartate oxidase (DDO or DASPO, EC 1.4.3.1) is a FAD-containing enzyme that selectively deaminates bicarboxylic D-amino acids, such as D-aspartate (D-Asp), NMDA, and D-glutamate (Still and Buell, 1949; Van Veldhoven et al., 1991; D'Aniello et al., 1993). DDO is expressed in both humans and rats (Van Veldhoven et al., 1991; Schell et al., 1997; Zaar et al., 2002). In the rat brain, DDO activity is nearly absent during embryonic and perinatal stages and progressively increases during adulthood (Van Veldhoven et al., 1991). Accordingly, free D-Asp (DDO endogenous substrate) shows a reciprocal temporal occurrence because it is substantially enriched in the embryonic brain, rapidly declines after birth, and remains at low levels throughout the adulthood (Dunlop et al., 1986; Neidle and Dunlop, 1990; Hashimoto et al., 1993, 1995; Sakai et al., 1998; Wolosker et al., 2000). Notably, in homogenates from human fetal prefrontal cortex (PFC), the amount of free D-Asp even exceeds that of the L-aspartate (L-Asp) at gestational week 14, before substantially decreasing at postnatal stages (Hashimoto et al., 1993). The peculiar temporal pattern of DDO expression in the rat brain suggests that this catabolic enzyme acts to maintain low levels of D-Asp during postnatal brain development. However, the biological meaning of the prominent postnatal DDO activity is still unclear. Likewise, it is still unknown whether abundant free D-Asp levels play any physiological role during embryonic and perinatal brain development. Recent evidence from mouse brain tissue slices has shown that free D-Asp activates the NMDA receptors (NMDARs) via binding to the GluN2 subunit (Errico et al., 2008a, b; 2011a, b). In this line, studies performed in mice lacking the $D d o$ gene $\left(D d o^{-1-}\right)$ and in chronically D-Asp-treated mice have demonstrated that the resulting increase in free D-Asp in the brain (Errico et al., 2006; Huang et al., 2006) affects NMDAR-dependent transmission (Errico et al., 2008a, b, 2011a, b, 2014; Krashia et al., 2015), early- and late-phase hippocampal LTP (Errico et al., 2008b, 2014), dendritic length and spine density of hippocampal and cortical neurons (Errico et al., 2014), and spatial memory abilities (Errico et al., 2008a, 2011a, b). Furthermore, higher levels of D-Asp in Ddo ${ }^{-1-}$ mice are also associated with greater brain connectivity, as well as reduced sensorimotor gating deficits and abnormal circuits activation induced by the hallucinogenic drug, phencyclidine, as assessed by fMRI (Errico et al., 2015b). Consistent with these findings in mice, a human

Received Oct. 27, 2015; revised Jan. 5, 2016; accepted Jan. 23, 2016.

Author contributions: F.E. and A.U. designed research; D.P., L. Cristino, S.S., S.K., C.B., L.L., T.N., R.I., E.F., O.A., S. Migliarini, G.M., and M.J.S. performed research; V.D.N., M.P., L.P., S. Maione, and L. Chiariotti analyzed data; F.E. and A.U. wrote the paper.

A.U. was supported by 2013 National Alliance for Research on Schizophrenia and Depression Independent Investigator Grant 20353 from the Brain and Behavior Research Foundation. F.E. was supported by 2015 National Alliance for Research on Schizophrenia and Depression Young Investigator Grant 23968 from the Brain and Behavior Research Foundation, and the Italian Ministry of Education, Universities and Research (FIRB Call-Program Futuro in Ricerca 2010, Project RBFR10XCD3). S.S. and L.P. were supported by Fondo di Ateneo per la Ricerca. L. Chiariotti was supported by Epigenomics Flagship Project (CNR). We thank Wolfgang Kelsch, Francisco Zafra, and Darrick Balu for critical discussion; and Marta Squillace, Giuseppe Aceto, and Anna Di Maio for technical support.

The authors declare no competing financial interests.

*D.P., F.E., and L. Cristino contributed equally to this study as co-first authors.

Correspondence should be addressed to either of the following: Dr. Lorenzo Chiariotti, Department of Molecular Medicine and Medical Biotechnology, University of Naples Federico II, Via Pansini 5, 80131 Naples, Italy, E-mail: chiariot@unina.it; or Dr. Alessandro Usiello, Ceinge Biotecnologie Avanzate, Via G. Salvatore 486, 80145 Naples, Italy, E-mail: usiello@ceinge.unina.it.

DOI:10.1523/JNEUROSCI.3881-15.2016

Copyright $\odot 2016$ the authors $\quad 0270-6474 / 16 / 363065-15 \$ 15.00 / 0$
DDO gene variant (rs3757351), yielding reduced expression levels of DDO mRNA in postmortem prefrontal cortex, is associated with both greater prefrontal gray matter and activity (fMRI) during working memory processing in healthy subjects (Errico et al., 2014).

Based on the basic and translational interest of free D-amino acids in brain physiology and in the treatment of psychiatric disorders, such as schizophrenia (Tsai et al., 1998, 2006; HerescoLevy et al., 2005; Lane et al., 2005; Kantrowitz et al., 2010), we aim here to do the following: (1) elucidate the molecular mechanism regulating the postnatal cerebral expression of DDO; (2) investigate how the targeted deletion of $D d o$ affects extracellular levels of free D-Asp in the brain; and (3) clarify the physiological relevance of this enzyme in the mammalian brain during aging.

\section{Materials and Methods}

Animals. All experiments were performed on male animals. C57BL/6J mice were purchased from The Jackson Laboratory. Knock-out mice for the $D d o$ gene were generated and genotyped by PCR as described previously (Errico et al., 2006). Wild-type (Ddo ${ }^{+/+}$) and knock-out $\left(D d o^{-/-}\right)$ mice, derived from mating of heterozygous $\left(\mathrm{Ddo}^{+/-}\right)$mice, were backcrossed to the F5 generation to C57BL/6J strain. Mice were housed in groups $(n=4$ or 5$)$ in standard cages $(29 \times 17.5 \times 12.5 \mathrm{~cm})$ at constant temperature $\left(22 \pm 1^{\circ} \mathrm{C}\right)$ and maintained on a $12 / 12 \mathrm{~h} \mathrm{light/dark}$ cycle, with food and water ad libitum. All research involving animals was performed in accordance with the European directive 86/609/EEC governing animal welfare and protection, which is acknowledged by the Italian Legislative Decree no. 116 (January 27, 1992). Animal research protocols were also reviewed and consented to by a local animal care committee. All efforts were made to minimize the animal's suffering.

Mouse tissue collection. Whole brains were collected from C57BL/6J mice at different developmental stages, including the following time points: embryonic day $15(\mathrm{E} 15 ; n=5)$, postnatal day $0(\mathrm{P} 0 ; n=2), \mathrm{P} 7$ $(n=3), \mathrm{P} 14(n=6), \mathrm{P} 21(n=3), \mathrm{P} 30(n=3)$, and P60 $(n=3)$. The PFC and ventral midbrain were dissected out from 3 -month-old $D d o^{+/+}$and $D d o^{-1-}$ mice (PFC, $n=5 /$ genotype; midbrain, $n=4 /$ genotype). Mice were killed, and the whole brain, PFC, or midbrain was dissected out within $20 \mathrm{~s}$ on an ice-cold surface. All tissue samples were pulverized in liquid nitrogen and stored at $-80^{\circ} \mathrm{C}$ for subsequent processing.

HPLC analyses. Brain tissue samples were analyzed as previously reported (Topo et al., 2010), with minor modifications. They were homogenized in 1:20 (w/v) $0.2 \mathrm{M}$ TCA, sonicated ( 3 cycles, $10 \mathrm{~s}$ each), and centrifuged at $10,000 \times g$ for $10 \mathrm{~min}$. The precipitated protein pellets were stored at $-80^{\circ} \mathrm{C}$ for protein quantification, whereas the supernatants were neutralized with $\mathrm{NaOH}$ and subjected to precolumn derivatization with o-phthaldialdehyde (OPA)/ $\mathrm{N}$-acetyl-L-cysteine in $50 \%$ methanol. Enantiomer derivatives were then resolved on a Simmetry C8 $5 \mu \mathrm{m}$ reversed-phase column (Waters, $4.6 \times 250 \mathrm{~mm}$ ), in isocratic conditions $(0.1 \mathrm{~m}$ sodium acetate buffer, $\mathrm{pH} 6.2,1 \%$ tetrahydrofuran, 1 $\mathrm{ml} / \mathrm{min}$ flow rate). A washing step in $0.1 \mathrm{~m}$ sodium acetate buffer, $3 \%$ tetrahydrofuran and $47 \%$ acetonitrile, was performed after every single run. Identification and quantification of D-and L-Asp was based on retention times and peak areas, compared with those associated with external standards. The two enantiomers were detected as well-defined peaks at the retention time of $4.75 \pm 0.1 \mathrm{~min}$ and $5.33 \pm 0.1 \mathrm{~min}$ for D-and L-Asp, respectively (see Fig. 1 $a, b$ ). The identity of D-Asp and L-Asp peaks was confirmed either by the selective degradation catalyzed by the RgDAAO M213R variant (Sacchi et al., 2002) (see Fig. 1a, inset) and StLASPO (Bifulco et al., 2013), respectively, or by the addition of external standards (see Fig. $1 b$, inset). The samples were added with $10 \mu \mathrm{g}$ of the enzymes, incubated at $30^{\circ} \mathrm{C}$ for $30 \mathrm{~min}$, and then derivatized (Topo et al., 2010). Total protein content of homogenates was determined using the Bradford assay method after resolubilization of the TCA precipitated protein pellets. The detected total concentration of D-Asp and L-Asp in homogenates was normalized by the total protein content. Data on the ontogenetic occurrence of D-and L-Asp in the whole brain were analyzed by one-way ANOVA (age effect); data on D-and L-Asp occurrence in the 
PFC and midbrain of $D d o^{+/+}$and $D d o^{-/-}$mice were analyzed by Student's $t$ test (genotype effect).

Dialysates were analyzed for D-Asp, L-Asp, and L-Glu content, as previously described (Guida et al., 2015). The HPLC system comprised a Varian ternary pump (model 9010), a C18 reverse-phase column, a Varian refrigerated autoinjector (model 9100), and a Varian fluorimetric detector. Dialysates were precolumn derivatized with OPA (10 $\mu$ l dialysate $+10 \mu \mathrm{lOPA}$ ) and amino acid conjugates resolved using a gradient separation. The mobile phase consisted of the following two components: (1) $0.2 \mathrm{M}$ sodium phosphate buffer, $\mathrm{pH} 5.8,0.1 \mathrm{M}$ citric acid, $\mathrm{pH}$ 5.8; and (2) $90 \%$ acetonitrile. The identity of D-Asp peak was confirmed by incubating a parallel sample with $20 \mu \mathrm{g}$ of purified DDO (Negri et al., 1999) for $15 \mathrm{~min}$ at $37^{\circ} \mathrm{C}$ and chromatographed as above. Identification and quantification of D-and L-Asp, as well as L-Glu, were performed as reported above. Data were collected by a Dell PC system 310 interfaced by Varian Star 6.2 control data and acquisition software. Amino acid extracellular levels were expressed as nM (D-Asp and L-Asp) or $\mu \mathrm{M}$ (L-Glu) concentration. Data were analyzed by two-way ANOVA with repeated measures (genotype $\times$ time).

Enzymes. Recombinant Rhodotorula gracilis D-amino acid oxidase M213R variant (RgDAAO M213R; EC 1.4.3.3) and Sulfolobus tokodaii L-aspartate oxidase (StLASPO; EC 1.4.3.16) were overexpressed in Escherichia coli cells and purified as previously described (Sacchi et al., 2002; Bifulco et al., 2013). Final RgDAAO M213R and StLASPO preparations had a specific activity of $5.8 \mathrm{U} / \mathrm{mg}$ protein on D-Asp as substrate and 0.98 $\mathrm{U} / \mathrm{mg}$ protein on $\mathrm{L}-\mathrm{Asp}$ as substrate, respectively, whereas they were fully inactive on the opposite enantiomers. Recombinant DDO (EC 1.4.3.1) from beef kidney was expressed in E. coli, and the purified preparation showed a specific activity of $5 \mathrm{U} / \mathrm{mg}$ protein (Negri et al., 1999).

In vivo microdialysis. Microdialysis experiments were performed in awake and freely moving mice as previously reported (Guida et al., 2015). Three-month-old $D d o^{+1+}$ and $D d o^{-1-}$ mice were anesthetized with pentobarbital (50 mg/kg, i.p.), and the concentric microdialysis probes were stereotaxically implanted into the PFC area (anteroposterior: 1.5 $\mathrm{mm}$; L: 0.3; and ventral: $3.3 \mathrm{~mm}$ below the dura) and secured to the skull using stainless steel screws and dental cement. Microdialysis probes were constructed with $22 \mathrm{G}$ (0.41 mm I.D., $0.7 \mathrm{~mm}$ O.D.) stainless steel tubing: inlet and outlet cannulae $(0.04 \mathrm{~mm}$ I.D., $0.14 \mathrm{~mm}$ O.D.) consisted of fused silica tubing. The probe had a tubular dialysis membrane (Enka) $1.3 \mathrm{~mm}$ in length. After a postoperative recovery period of $\sim 48 \mathrm{~h}$, dialysis was commenced with ACSF ( $147 \mathrm{~mm} \mathrm{NaCl}, 2.2 \mathrm{~mm} \mathrm{CaCl}, 4 \mathrm{~mm} \mathrm{KCl}, \mathrm{pH}$ 7.2). Animals were perfused at a rate of $1.2 \mu \mathrm{l} / \mathrm{min}$ using a Harvard Apparatus infusion pump (model 22). After an equilibration period of 60 min, samples were collected every $30 \mathrm{~min}$ for a total time length of 180 min. The last dialysate fraction $(150-180 \mathrm{~min})$ was collected in the absence of calcium by perfusing with $\mathrm{Ca}^{2+}$-free ACSF solution. Dialysates were analyzed for D-Asp, L-Asp, and L-Glu content using HPLC coupled with the fluorimetric detection method.

In situ hybridization (ISH). ISH analysis was performed on sagittal sections from E15, P0, P14, P30, and P60 C57BL/6J brains ( $n=3$ per age), $D d o^{+1+}$ or $D d o^{-1-}$ brains $(n=3$ per genotype) according to a protocol previously described (Migliarini et al., 2013). ${ }^{35}$ S-labeled Ddo antisense riboprobes $(1.9 \mathrm{~kb})$ were used. Hybridized sections were exposed to Biomax MR x-ray films (Kodak) for 7-9 d. Sections were examined using brightfield light microscopy. To obtain clearer and more defined images, less disturbed by the background noise, pseudocolor scale of the images was used. Signals were pseudocolored with the National Institutes of Health ImageJ Lookup Table 16_colors.

$R N A$ extraction and $q R T-P C R$. Total RNA was extracted by TRIZOL reagents (Ambion, Invitrogen) according to the manufacturer's instructions. The integrity of the RNA was assessed by denaturing agarose gel electrophoresis (presence of sharp 28S, 18S, and 5S bands) and spectrophotometry (NanoDrop 2000, Thermo Scientific). Total RNA was purified to eliminate potentially contaminating genomic DNA using recombinant DNase (QIAGEN). A total of $1 \mu \mathrm{g}$ of total RNA of each sample was reverse-transcribed with QuantiTect Reverse Transcription (QIAGEN) using oligo-dT and random primers according to the manufacturer's instructions. qRT-PCR amplifications were performed using LightCycler 480 SYBR Green I Master (Roche Diagnostic) in a LightCy- cler 480 Real Time thermocycler (Roche). The following protocol was used: $10 \mathrm{~s}$ for initial denaturation at $95^{\circ} \mathrm{C}$ followed by 40 cycles consisting of $10 \mathrm{~s}$ at $94^{\circ} \mathrm{C}$ for denaturation, $10 \mathrm{~s}$ at $60^{\circ} \mathrm{C}$ for annealing, and $6 \mathrm{~s}$ for elongation at $72^{\circ} \mathrm{C}$ temperature. The following primers were used for mouse Ddo cDNA amplification: Ddo forward 5'-ACCACCAGTAATG TAGCGGC3' and $D d o$ reverse $5^{\prime}$-GGTACCGGGGTATCTGCAC- $3^{\prime} ; \beta$-actin gene was used as housekeeping gene forPCR: $\beta$-actin forward $5^{\prime}$-CT AAGGCCAACCGTGAAAAG-3' and $\beta$-actin reverse $5^{\prime}$-ACCAG AGGCATACAGGGACA-3'. Data were analyzed by one-way ANOVA (age effect).

5-Aza-2'-deoxycytidine treatment of primary cortical neurons. Cortical neurons were prepared from brains of 17-day-old C57BL/6J mouse embryos as previously described (Sisalli et al., 2014). Briefly, the mice were first anesthetized and then killed by cervical dislocation to minimize the animals' pain and distress. Dissection and dissociation were performed in $\mathrm{Ca}^{2+} / \mathrm{Mg}^{2+}$-free buffer saline (HBSS $1 \times$ ). Tissues were incubated with trypsin for $20 \mathrm{~min}$ at $37^{\circ} \mathrm{C}$ and dissociated by trituration in culture medium. Cells were plated at $3.5-5 \times 10^{6}$ in $60 \mathrm{~mm}$ plastic Petri dishes, precoated with poly-D-lysine $(20 \mathrm{mg} / \mathrm{ml})$, in MEM/F12 (Invitrogen)containing glucose, $5 \%$ deactivated FBS, and 5\% horse serum (Invitrogen), glutamine, and antibiotics. Ara-C ( $10 \mathrm{~mm}$ ) was added within $48 \mathrm{~h}$ of plating to prevent non-neuronal cell growth. Neurons were cultured at $37^{\circ} \mathrm{C}$ in a humidified $5 \% \mathrm{CO}_{2}$ atmosphere. Forty-eight hours of treatment of neuronal cultures was done with 5-aza-2'-deoxycytidine at a final concentration of $5 \mu \mathrm{M}$ (Sigma-Aldrich). All the experiments on primary cortical neurons were performed according to the procedures described in experimental protocols approved by the Ethical Committee of the Federico II University of Naples. RNA extraction and qRT-PCR were performed as described above.

DNA extraction and methylation analysis. DNA from frozen brain tissue samples was extracted using the ZR Genomic DNA tissue Midi Prep kit (Zymo Research). The integrity and the amount of genomic DNA were assessed by $0.8 \%$ agarose gel electrophoresis and Qubit Fluorometric Quantitation (Invitrogen). Sodium bisulfite conversion was performed using EZ DNA Methylation Kit (Zymo Research). A total of $2 \mu \mathrm{g}$ of genomic DNA was used according to the manufacturer's instruction. Methylation status was assessed through a strategy based on the locusspecific amplification of bisulfite-treated genomic DNA, amplifying each amplicon separately, followed by Illumina MiSeq sequencing. Fusion primers were designed to generate tiled amplicons ranging in size between 400 and 500 bp segments. Sequence of the bisulfite-specific primers used for this analysis were as follows: Ddo PR1 forward $5^{\prime}$ gtgtgtttTtgaggaggtgaTaTtTa-3' (nt position from -468 to -444 ) and Ddo PR1 reverse 5' -aActtaccctccattAAtccatAcc-3' (nt -88 to -63 ) for the Ddo promoter region 1 (amplicon size $405 \mathrm{bp}$ ) and Ddo PR2 forward $5^{\prime}$-ggTtggtggTaagTtgaagttTttg-3' (nt -229 to -204 ) and Ddo PR2 reverse $5^{\prime}$-acccctaaaatcccaAaAtAcatac-3' (nt 118 to 143) for the Ddo promoter region 2 (amplicon size 372). The capital letters in the primers sequences indicate the original $\mathrm{C}$ or G, respectively. The methods involved two PCR steps, following Illumina recommended procedure. The pool of amplicons was subjected to sequencing using MiSeq system (V3 reagents kits). Sequencing was performed by $281 \times 2$ cycles (paired-end sequencing). Sequences in FASTQ format by Illumina sequencing machine were initially processed with Paired-End reAd mergeR (PEAR) data for an initial quality filtering and assembling (R1 plus R2). Only those sequences with a threshold quality score of $\geq 30$, a read length between 400 and $500 \mathrm{nt}$, and an overlapping region within paired-end reads of $40 \mathrm{nt}$ were processed with PReprocessing and INformation of SEQuence (Prinseq) to obtain FASTA for further analysis. On average, $\sim 232,000$ (range: 139,241-368,083) amplicon reads were obtained from each sample. Reads were aligned to the bisulfite converted reference sequence. Methylation states were estimated by observing base calls (T/C) at $\mathrm{CpG}$ sites in the mapped reads. Reads with ambiguous calls at the $\mathrm{CpG}$ dinucleotide were removed. After filtering, an average of $\sim 200,000$ (range: 119,040-317,832) amplicon reads were obtained from each sample. Data were analyzed by one-way ANOVA (age effect).

Immunohistochemistry. Ddo ${ }^{+1+}$ and $D d o^{-1-}$ mice at $0.5,3,6,10$, and 13 months of age ( $n=3$ per genotype and age) were deeply anesthetized and transcardially perfused with a saline solution followed by $4 \%$ PFA in 
$0.1 \mathrm{M}$ phosphate buffer. Morphological investigation of microglia was performed by incubation of sections with rabbit anti-Iba-1 primary antibody (1:1000 anti-ionized calcium-binding adapter molecule 1; Wako Chemicals) and revealed by appropriate secondary antibody (goat antirabbit, IgG-conjugated AlexaFluor-488; 1:1000; Invitrogen). The analysis of microglia was performed as previously described (Cristino et al., 2015). Briefly, quantitative analysis was performed by counting, for each phenotype, the bisbenzimide-counterstained cells with nucleus on the focal plane within a box measuring $2 \times 10^{4} \mu \mathrm{m}^{2}$ in the substantia nigra pars compacta (SN). Resting microglia displayed small somata bearing long, thin, ramified processes. Activated microglia exhibited marked cellular hypertrophy and retraction of processes such that the process length was less than the diameter of the soma compartment. Dystrophic microglia was recognized by debris consisting of cells displaying fragmented processes as previously demonstrated in humans (Streit et al., 2009, 2014).

Moreover, serial $10 \mu \mathrm{m}$ PFC and SN frozen sections were collected onto glass slides (Menzel) to be processed for Neuronal Nuclear (NeuN) marker immunoperoxidase (PFC) and for activated caspase-3/NeuN (PFC), or activated caspase-3/tyrosine hydroxylase (TH) (SN) immunofluorescence counterstained with DAPI. For NeuN immunoperoxidase staining, the PFC sections were reacted for $10 \mathrm{~min}$ in $0.1 \% \mathrm{H}_{2} \mathrm{O}_{2}$ to inactivate endogenous peroxidase activity and then incubated with $10 \%$ normal goat serum (Vector Laboratories) in $0.1 \mathrm{M}$ Tris-buffered saline, pH 7.6, containing $0.3 \%$ Triton X-100 and $0.05 \%$ sodium azide (Sigma). The sections were then incubated overnight at $4^{\circ} \mathrm{C}$ with normal goat serum diluted (range 1:200-1:400) rabbit polyclonal anti-NeuN (Abcam). After several rinses, the sections were incubated at room temperature for $2 \mathrm{~h}$ in biotinylated goat anti-rabbit IgGs (Vector Laboratories) followed $1 \mathrm{~h}$ by incubation in the avidin-biotin complex (ABC Kit; Vectastain, Vector) diluted in Tris-buffered saline according to the manufacturer's indications and then in $0.05 \%$ DAB for 10 min (DAB Sigma Fast, Sigma-Aldrich). Immunohistochemical study of activated caspase-3 in PFC and SN was performed by incubation with goat antiactivated caspase-3 (Santa Cruz Biotechnology) revealed by specific Alexa-488 secondary donkey anti-IgG antibody (Invitrogen) counterstained with DAPI. For activated caspase-3/NeuN or caspase-3/TH immunofluorescence, the sections were incubated with a mixture of goat anti-active caspase-3 (Santa Cruz Biotechnology) with rabbit polyclonal anti-NeuN (Abcam) or mouse anti-TH (Abcam) and revealed by a mixture of Alexa-488 and Alexa-546 secondary donkey anti-IgG antibodies (Invitrogen). TUNEL assay was performed on $n=3$ sections (each from the rostral, medial, and caudal level of PFC or SN to be representative of the entire region) by using a commercial kit (Merck, Millipore) in accordance with the manufacturer's instructions. Caspase- 3 and TUNEL assay were analyzed by Leica DMI6000 microscope equipped with appropriate filters and deconvolution MetaMorph LAS AF 2.2.0 software (Leica). Quantitative analysis was performed by counting the activated caspase3 -positive cells in $6.25 \times 10^{4} \mu \mathrm{m}^{2}$ of PFC area/section $(n=3$ sections per animal) and activated caspase-3/TH-positive neurons on $n=200 \pm 20$ randomly selected TH-immunoreactive neurons ( $n=4 \mathrm{SN}$ sections per each genotype and age). Furthermore, activated caspase-3/NeuNpositive neurons were counted on $n=200 \pm 20 \mathrm{NeuN}$-immunoreactive neurons randomly selected $(n=3$ PFC sections per genotype of 13 month-old mice). Statistical analysis was performed by two-way ANOVA (genotype $\times$ age), followed by Fisher's post hoc analysis between genotypes, when required.

Lipofuscin quantification. Sagittal $100-\mu \mathrm{m}$-thick Vibratome-cut sections obtained from $D d o^{+/+}$and $D d o^{-1-}$ PFA-fixed brains at 0.5 and 3 months of age ( $n=3$ per genotype and age) were used. Free-floating sections were incubated with mouse anti-TH and subsequently with an Oregon Green 488 goat anti-mouse secondary antibody (Invitrogen) to label dopaminergic neurons, and counterstained with DAPI to identify cortical layers. For each animal, 7-10 images at the level of the SN and of the PFC (layer V-VI) were acquired for the DAPI, red, and green channels at $60 \times$ magnification with a Nikon A1 confocal microscope. Each image was a projection of a $Z$-stack with $20 Z$-steps at $0.5 \mu \mathrm{m}$ intervals. Lipofuscin inclusion bodies were visualized as red autofluorescent gran- ules with the $561 \mathrm{~nm}$ laser excitation and analysis of their volume was performed using Imaris 7.2.3 software (Bitplane, Scientific Software).

\section{Results}

Age-related decrease in D-aspartate levels mirrors progressive increased expression in Ddo mRNA in the mouse brain

It has been reported that in the human and rat brain free D-Asp concentration decreases after birth and remains at low levels throughout postnatal life (Hashimoto et al., 1993; Schell et al., 1997; Sakai et al., 1998; Wolosker et al., 2000). Here we sought to investigate whether such ontogenetic variations occur also in the mouse brain. In this regard, we quantified the content of both free D-Asp and L-Asp in brain homogenates at different time points, between embryonic day 15 (E15) and adult postnatal day 60 (P60) by HPLC. At E15, the concentration of D-Asp and L-Asp detected in whole-brain homogenates were $5.10 \pm 0.63$ and $25.33 \pm 4.13 \mathrm{nmol} / \mathrm{mg}$ protein, respectively. Consistently to humans and rats (Dunlop et al., 1986; Neidle and Dunlop, 1990; Hashimoto et al., 1993, 1995; Sakai et al., 1998; Wolosker et al., 2000), free D-Asp content in the mouse brain decreased significantly after birth (one-way ANOVA, $F_{(6,18)}=9.394 ; p<0.0001$; Fig. 1c). Post hoc comparison revealed a significant drop in free $\mathrm{D}$-Asp concentration at $\mathrm{P} 7(3.45 \pm 0.20 \mathrm{nmol} / \mathrm{mg}$ protein; $p=$ 0.0192 , compared with E15), followed by a progressive decrease at subsequent developmental stages until P60 (1.81 \pm 0.28 $\mathrm{nmol} / \mathrm{mg}$ protein; $p=0.0343$, compared with P7; $p<0.0001$, compared with E15; Fig. 1c). On the other hand, no changes were detected in free L-Asp levels at the analyzed ages $\left(F_{(6,18)}=0.586\right.$; $p=0.7374$; Fig. 1d). Accordingly, the calculated D-Asp/total Asp ratio showed the same reduction profile observed for D-Asp during postnatal development $\left(F_{(6,18)}=4.215 ; p=0.0080\right.$; Fig. $\left.1 e\right)$.

At the same prenatal and postnatal time points, we also investigated $D$ do gene expression by qRT-PCR (Fig. $1 f$ ). Notably, the Ddo mRNA in the whole brain strongly increased during postnatal development (one-way ANOVA, $F_{(6,14)}=14.751 ; p<$ $0.0001)$. In particular, the relative expression of $D d o$ transcript was very low at E15 and P0 (0.03 \pm 0.01 and $0.07 \pm 0.02$, respectively), and progressively raised during postnatal stages, reaching a 25-fold increase at P60, compared with E15 (0.85 $\pm 0.10 ; p<$ 0.0001 , Fisher's post hoc) (Fig. $1 f$ ). Finally, we evaluated the spatial pattern of $D$ do mRNA transcriptional activation in the mouse brain during ontogenesis by ${ }^{35} \mathrm{~S}$ radioactive ISH (Fig. $1 g$ ). At E15 and P0, Ddo mRNA expression was detected within the ependymal cell layer of the telencephalic ventricles. At P14, several brain regions, such as the hippocampus, thalamus, and cerebellum, displayed intense Ddo mRNA expression in addition to the ependymal cell layer. At P30 and, more robustly at P60, Ddo transcript levels strongly increased in these areas and appeared pronounced also in the midbrain region, pons, olfactory bulbs, and cortex. In addition to high-intensity signal in specific regional districts, we observed in adults a widespread expression of Ddo mRNA throughout the brain.

\section{The state of methylation of the Ddo promoter controls Ddo mRNA expression in the mouse brain}

The temporal increase of $D$ do transcript levels observed by qRTPCR and ISH (Fig. $1 f, g$ ) is coherent with the progressive global decrease of free D-Asp found in the brain during the postnatal life (Fig. 1c). This evidence prompted us to investigate the regulatory mechanism of $D d o$ expression in the mouse brain. In particular, we evaluated whether the age-related increase in cerebral Ddo mRNA could be explained by epigenetic modifications occurring during the late phases of embryogenesis and/or the early postna- 
a

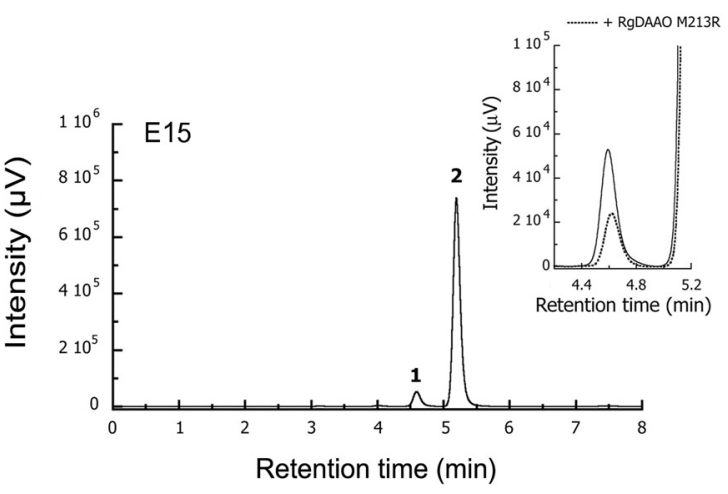

b

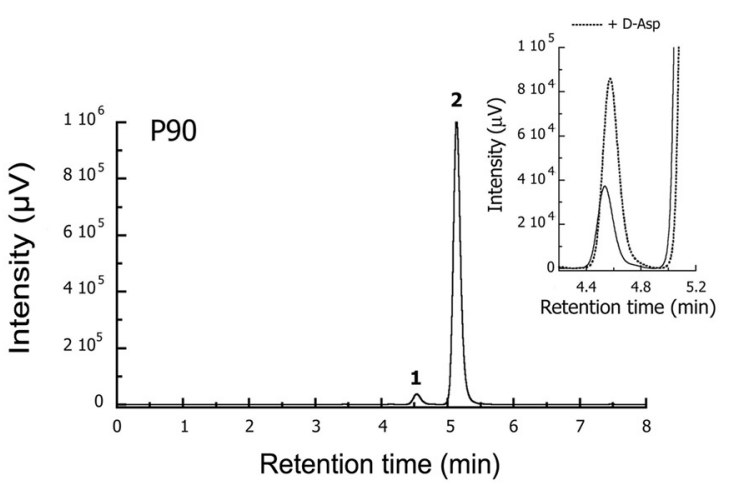

e

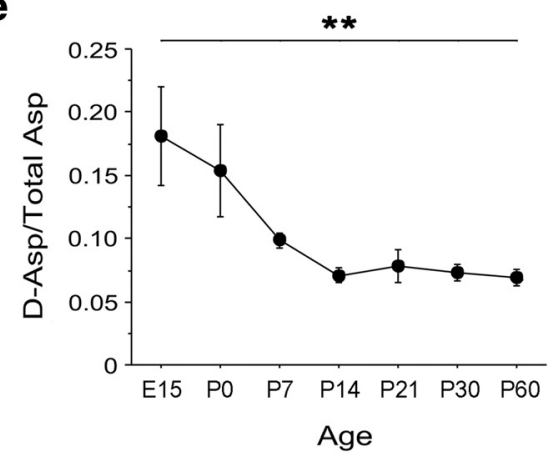

C

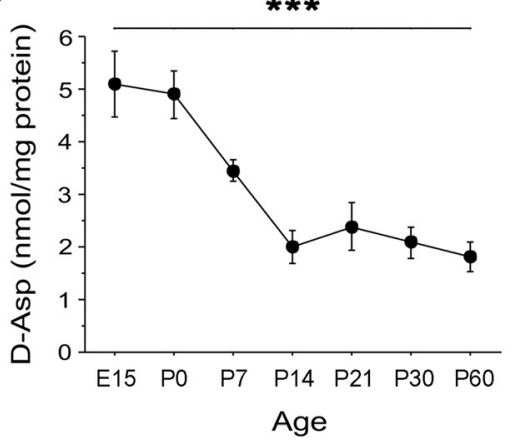

d

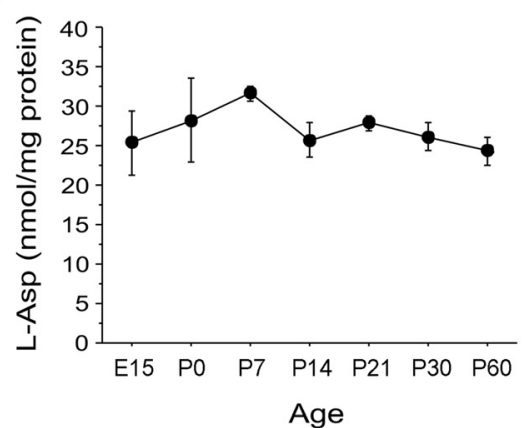

f

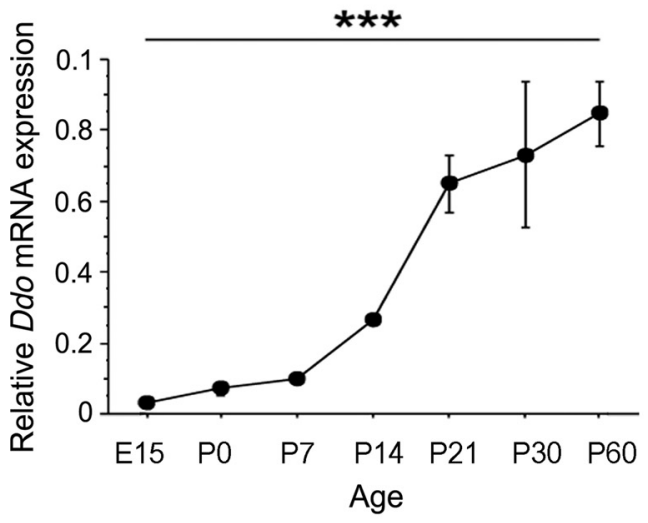

g
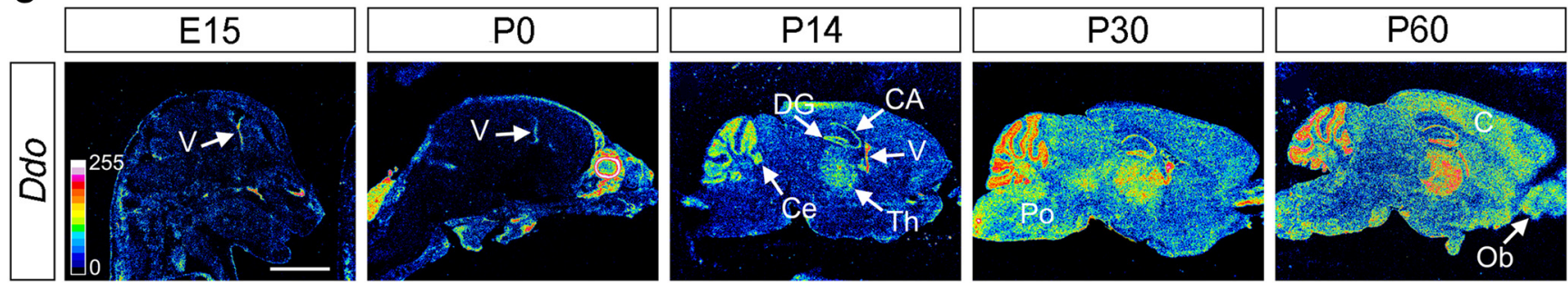

Figure 1. Variation in D-aspartate levels and Ddo mRNA expression in the mouse brain during ontogenesis. $\boldsymbol{a}, \boldsymbol{b}$, Examples of HPLC chromatograms illustrating the detection of (1) D-aspartate (D-Asp) and (2) L-aspartate (L-Asp) obtained from (a) E15 and (b) P90 brain tissue samples. The identity of the peak corresponding to D-aspartate (4.66 \pm 0.09 min) was verified by treating E15 samples with $10 \mu \mathrm{g}$ RDDAOOM213R ( $\boldsymbol{a}$, inset, dotted line), and by adding the external standard to P90 samples ( $\boldsymbol{b}$, inset, dotted line). D-Aspartate retention time is reported as the mean $\pm S D ; n=34$. $c-e$, Average content of $D$-aspartate, L-aspartate, and D-aspartate/total aspartate ratio in total brain of $(57 \mathrm{BL} / 6 \mathrm{~J} \mathrm{mice} \mathrm{at} \mathrm{different} \mathrm{ages} \mathrm{(E15,} n=$ $5 ; \mathrm{PO}, n=2 ; \mathrm{P} 7, n=3 ; \mathrm{P} 14, n=6 ; \mathrm{P} 21, \mathrm{P} 30$, and P60, $n=3$ ). The amount of (c) D-aspartate and (d) L-aspartate in the brain homogenates, detected by HPLC, was normalized by the total protein content of each sample. $f$, Analysis of $D$ do mRNA expression performed by qRT-PCR on a different set of whole brains from $(57 \mathrm{BL} / 6 \mathrm{~J}$ mice at different ages $(n=3$ per age). Quantity means of transcript were normalized to $\beta$-actin housekeeping gene. ${ }^{* *} p<0.01$ (one-way repeated-measures ANOVA). ${ }^{* * *} p<0.0001$ (one-way repeated-measures ANOVA). Data are mean \pm SEM. $g$, Representative pseudocolor autoradiographs from sagittal sections throughout the mouse brain at E15, P0, P14, P30, and P60 showing Ddo mRNA expression pattern. The relationship between autoradiographic signal intensity (from 0 to 255) and the pseudocolor images is scaled by pseudocolor bars (from blue to white). Scale bar, $750 \mu \mathrm{m}$. V, Ependymal cell layer of the ventricle; CA, cornu ammonis area; Ce, cerebellum; DG, dentate gyrus; Th, thalamus; $\mathrm{Po}$, pons; C, cortex; $0 \mathrm{~b}$, olfactory bulb. 
tal stages of development. In this regard, we investigated the methylation state of the putative promoter region of the Ddo gene at different prenatal and postnatal developmental stages, from E15 to P60, using the same whole brain samples tested for Ddo mRNA quantification (Fig. 1f). DNA methylation analysis was assessed through a strategy based on the locus-specific amplification of bisulfite-treated genomic DNA. We covered two overlapping genomic regions surrounding the transcription start site (TSS): Ddo regulatory region 1 (RR1), spanning nucleotides -443 to 88 and including 6 CpG sites (positions $-363,-330$, $-318,-242,-175,-125)$, and $D$ do regulatory region 2 (RR2) spanning nucleotides -185 to 150 and including 4 CpG sites (positions $-175,-125,50,113$ ), the first two of which coincided with the last two located most $3^{\prime}$ in RR1 (Fig. 2a). At each CpG site, we observed that the methylation degree progressively decreased from E15 to adult stages (one-way ANOVA, $p=0.0003$ for CpG 113, $p<0.0001$ for all other CpG sites) (Fig. 2b). On average, the methylation state of the $8 \mathrm{CpG}$ sites lying in the Ddo gene region from nucleotides -363 to 113 gradually decreased from $\sim 60 \%$ in E15 brains to $\sim 30 \%$ at P21-P60 stages $\left(F_{(6,14)}=\right.$ 39.887; $p<0.0001$; Fig. $2 c)$. Overall, these results for the first time highlight the occurrence of a developmentally regulated DNA demethylation process at the putative $D d o$ gene promoter.

To assess whether the progressive demethylation of the Ddo regulatory region could influence the gradual postnatal increase in Ddo mRNA levels, we then investigated whether "forced" alteration in DNA methylation state was linked to variations in cerebral Ddo expression. To this aim, we treated E17 cortical neurons (in which Ddo transcript is at the lowest expression level) either with vehicle or $5 \mu \mathrm{M} 5$-aza-2-deoxycytidine (azacitidine), a drug known to promote DNA demethylation both in cycling and in postmitotic cells (Marutha Ravindran and Ticku, 2005; Nelson et al., 2008; Gavin et al., 2013). Consistent with an epigenetic control of DNA methylation on Ddo mRNA transcription, qRT-PCR analysis showed that treatment with azacitidine caused an $\sim 4$-fold increase in transcriptional levels of Ddo (relative expression: $3.97 \pm 0.93$ ), compared with vehicletreated neurons (Fig. $2 d$ ).

\footnotetext{
Absence of DDO is associated with higher extracellular concentration of free $\mathrm{D}$-aspartate in the brain of $\mathrm{Ddo}^{-/-}$mice In the attempt to decipher the physiological relevance of the postnatal $D$ do promoter demethylation and, in turn, the influence of the concomitant Ddo mRNA upregulation on free D-Asp occurrence, we analyzed the neurochemical features of $D d o^{-/-}$adult brains. We used this animal model because it maintains, along the entire postnatal life, the physiological condition occurring during embryonic stages, when cerebral Ddo expression is suppressed and free D-Asp is abundant. Consistently, our ${ }^{35}$ S-radioactive ISH revealed that E15 Ddo ${ }^{+/+}$and $D d o^{-1-}$ brains were almost indistinguishable, as Ddo mRNA appeared barely detectable in both genotypes; in contrast, at P60, Ddo ${ }^{-1-}$ brains maintained an "embryo-like" inconsistent Ddo expression, whereas Ddo ${ }^{+/+}$ brains displayed robust and widespread Ddo mRNA detection (Fig. 3a).

Based on the lack of Ddo expression in knock-out brains, we measured the total amount of free D-Asp and L-Asp in the PFC of $\mathrm{Ddo}^{-1-}$ mice. As previously reported in other brain regions (Errico et al., 2006; Huang et al., 2006; Han et al., 2015), HPLC analysis indicated that also in the PFC the deletion of the Ddo gene yielded a strong increase in total D-Asp levels, compared with controls $(\sim 30$-fold $)\left(D d o^{+/+}: 0.49 \pm 0.04 \mathrm{nmol} / \mathrm{mg}\right.$ protein, $D d o^{-1-}: 15.91 \pm 1.46 \mathrm{nmol} / \mathrm{mg}$ protein; $p<0.0001$, Stu-
}

dent's $t$ test; Fig. $3 b$ ), whereas L-Asp content remained unchanged between genotypes $\left(D d o^{+/+}: 25.88 \pm 2.10 \mathrm{nmol} / \mathrm{mg}\right.$ protein, $D d o^{-l-}: 25.37 \pm 1.21 \mathrm{nmol} / \mathrm{mg}$ protein; $p=0.8397 ;$ Fig. $\left.3 c\right)$. In agreement with these detections, an increase of the same magnitude as for D-Asp was also found for the D-Asp/total Asp ratio in $D d o^{-1-}$ mice, compared with $\mathrm{Ddo}{ }^{+/+}$littermates $\left(\mathrm{Ddo}^{+/+}\right.$: $0.019 \pm 0.001, D_{d o}{ }^{-1-}: 0.38 \pm 0.02 ; p<0.0001$; Fig. $3 d$ ).

Then, we measured free D-Asp extracellular levels in the PFC of freely moving $\mathrm{Ddo} \mathrm{o}^{+/+}$and $\mathrm{Ddo} \mathrm{o}^{-/-}$mice by in vivo microdialysis, followed by HPLC analysis of the collected perfusates, as reported by Guida et al. (2015). Remarkably, we found that lack of $D$ do resulted in significantly $\sim 5$-fold higher free D-Asp extracellular levels in the cortical perfusates of $D d o^{-/-}$mice, compared with $\mathrm{Ddo} \mathrm{o}^{+/+}$animals (mean values: $D d o^{+/+}, 18.26 \pm 4.40 \mathrm{nM}$; $D d o^{-1-}, 101.50 \pm 8.41 \mathrm{nM}$; two-way ANOVA with repeated measures, genotype effect: $F_{(1,56)}=20.034, p=0.0005$; Fig. $3 e$ ). We finally collected the last dialysate fraction (150-180 $\mathrm{min}$ ) in $\mathrm{Ca}^{2+}$-free ACSF. Interestingly, under this condition, extracellular concentration of D-Asp was below the detection limit in both $D d o^{+/+}$and $D d o^{-1-}$ mice, suggesting that the removal of $\mathrm{Ca}^{2+}$ from the ACSF is able to prevent the cortical efflux of free D-Asp (Fig. $3 e$ ). In addition to D-Asp, we also detected the extracellular cortical concentration of free L-Asp and L-Glu. Surprisingly, despite that total L-Asp content was comparable between genotypes (Fig. 3c), a significant $\sim 2$-fold increase of extracellular L-Asp levels was apparent in the PFC of Ddo ${ }^{-1-}$ mice, compared with wild-type ones (mean values: $D d o^{+/+}, 84.00 \pm 2.44 \mathrm{nM} ; D d o^{-/-}$, $177.16 \pm 8.74 \mathrm{~nm} ; F_{(1,56)}=14.954, p=0.0017$; Fig. $\left.3 f\right)$. On the other hand, extracellular L-Glu concentrations detected in cortical perfusates were comparable between genotypes (mean values: $D d o^{+/+}, 1.02 \pm 0.03 \mu \mathrm{M}, D d o^{-/-}, 0.86 \pm 0.03 \mu \mathrm{M} ; F_{(1,32)}=$ 0.399, $p=0.5451$; Fig. $3 g$ ). As observed for D-Asp, extracellular levels of both L-Asp and L-Glu were undetectable when microdialysis was performed in a $\mathrm{Ca}^{2+}$-free ACSF (Fig. $3 f, g$ ).

\section{Nonphysiological increase of $\mathrm{D}$-aspartate in $\mathrm{Ddo} \mathrm{o}^{-/-}$brains is associated with age-related caspase- 3 activation and cell death in the prefrontal cortex}

Several works have indicated that free D-Asp activates NMDARdependent signaling and currents (Errico et al., 2015b). On the other hand, it is known that persistent stimulation of NMDARs at extrasynaptic site triggers oxidative stress and the activation of apoptotic/necrotic pathways (Lipton, 2008; Hardingham and Bading, 2010; Parsons and Raymond, 2014). Here, we examined whether constitutive exposure of cortical neurons to nonphysiological, higher extracellular D-Asp levels produces neurotoxic effects in the brain of $\mathrm{Ddo} \mathrm{o}^{-1-}$ mice during aging. Considering that caspase activation plays a pivotal role in neuronal apoptosis and represents the terminal event preceding cell death (Shalini et al., 2015), we measured the expression of active caspase-3 and DNA fragmentation by TUNEL staining in the infralimbic/prelimbic area of the PFC in Ddo ${ }^{-1-}$ mice at 3, 6, and 13 months of age (Fig. 4). Two-way ANOVA revealed a significant agedependent increase of caspase- 3 activation in $D d o^{-1-}$ mice (genotype, $F_{(1,12)}=1236.720, p<0.0001$; genotype $\times$ age, $F_{(2,12)}=$ $336.130, p<0.0001)$. More in detail, in line with detrimental effects of nonphysiological NMDAR stimulation produced by higher extracellular free D-Asp levels, we found a significantly increased percentage of activated caspase-3-positive cells in 6and 13-month-old $D d o^{-1-}$ mice, compared with age-matched controls (6-month-old: $D d o^{+/+}, 27.98 \pm 0.59, D_{d o}^{-1-}, 62.87 \pm$ $1.27 ; p<0.0001$; 13 -month-old: $D d o^{+1+}, 26.29 \pm 0.55, \mathrm{Ddo}^{-1-}$, $71.51 \pm 0.55 ; p<0.0001$; Fisher's post hoc; Fig. $4 a, b)$. The in- 
a

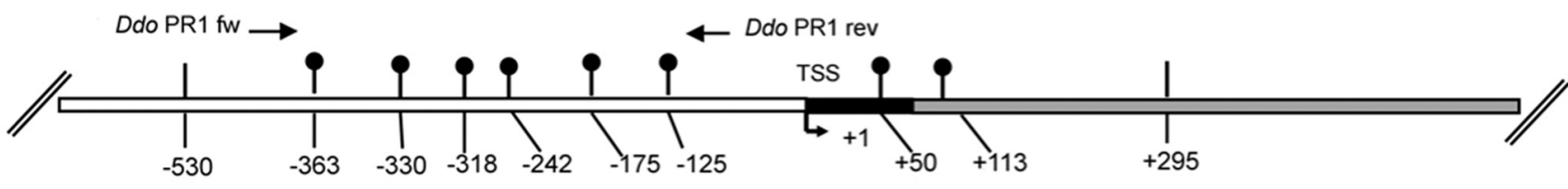

RR1

RR2

b
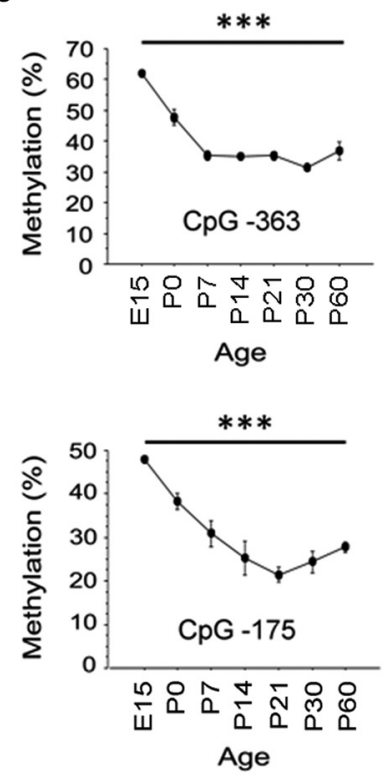

C
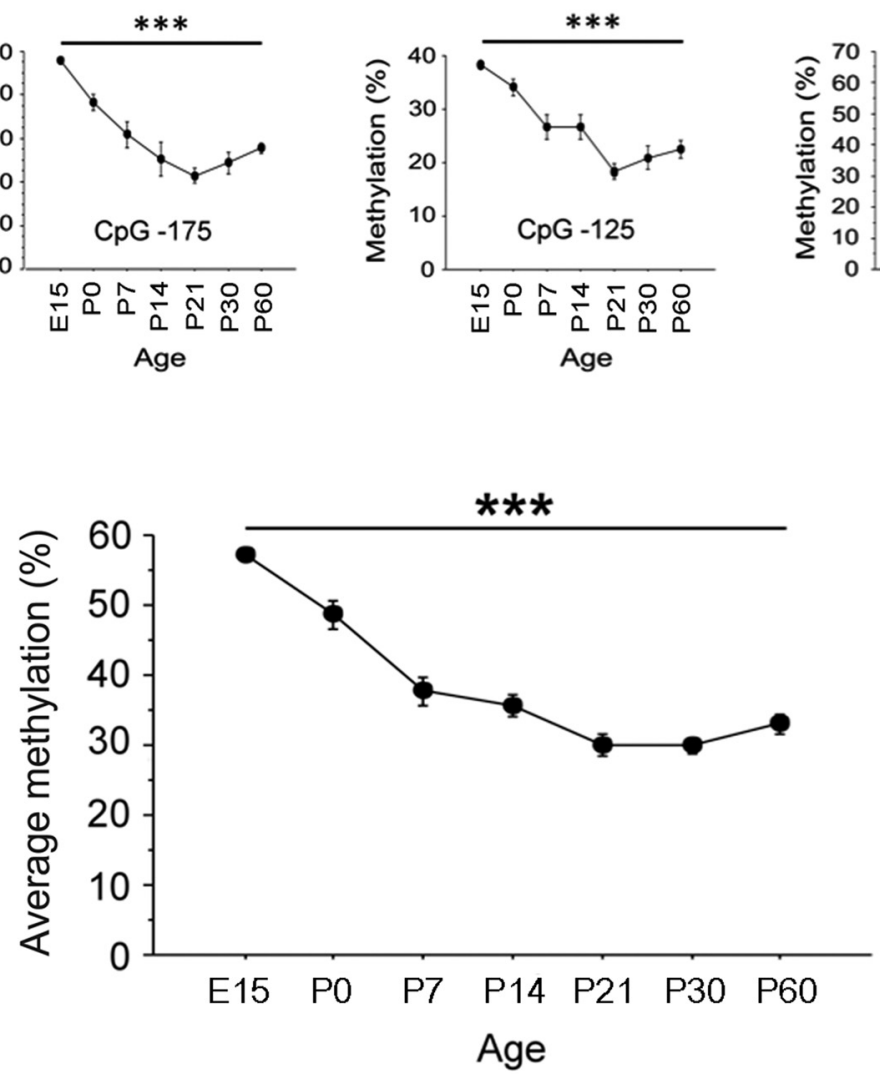
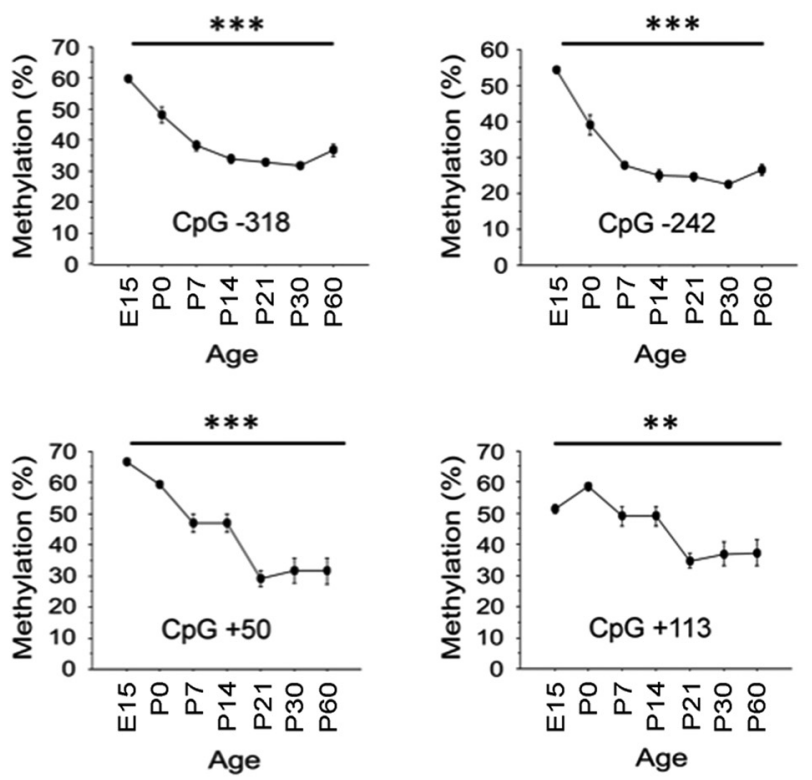

d

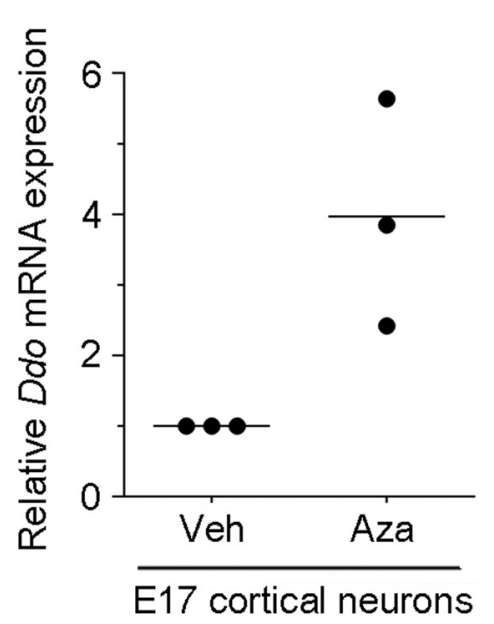

Figure 2. DNA methylation degree of the Ddo gene during mouse brain ontogenesis. $\boldsymbol{a}$, Structure of the putative mouse Ddo gene promoter. Arrow indicates the transcription start site (TSS, +1 ). White box represents the putative regulatory upstream region. Black box represents exon 1. Gray box represents first intron. Position of CpG sites is indicated as relative to TSS. Position of the primers used for bisulfite analysis is indicated by arrows at the top of the map (Ddo PR1 fw, Ddo PR1 rev, and Ddo PR2 fw, Ddo PR2 rev). RR1 and RR2 indicate the amplicons used to analyze the regulatory region 1 and 2, respectively. $\boldsymbol{b}, \boldsymbol{c}$, Graphs represent the percentage of methylation in $(\boldsymbol{b})$ the single $\mathrm{CpG}$ sites and (c) the average methylation degree of the eight $\mathrm{CpG}$ sites included in the RR1 and RR2 regions, at the indicated developmental stages. Whole-brain samples used for the methylation analysis are the same as that used to measure $D d o$ mRNA relative expression (Fig. $1 f$ ). $\boldsymbol{d}$, Relative $D d o$ mRNA expression in primary cortical neurons obtained from E17 brains of $\left(57 \mathrm{BL} / 6 \mathrm{~J}\right.$ mice, treated with vehicle (Veh) or $5 \mu \mathrm{m} 5$-aza-2' -deoxycytidine (azacitidine, Aza) for $48 \mathrm{~h}$. ${ }^{* *} p<0.01$ (one-way repeated-measures ANOVA). ${ }^{* * *} p<0.0001$ (one-way repeated-measures ANOVA). Data are mean \pm SEM.

crease of percentage of activated caspase-3-positive cells was mainly attributed to the pyramidal neurons of the PFC as observed by a reduction of the number of $\mathrm{NeuN}$-immunoreactive profile and by increased percentage of activated caspase-3/ $\mathrm{NeuN}$ immunocoexpression within the NeuN-positive neu- rons of 13-month-old Ddo ${ }^{-1-}$ mice $\left(D d o^{+/+}, 20.56 \pm 2.04 \%\right.$, $\mathrm{Ddo}^{-1-}, 67.45 \pm 2.30 \% ; p<0.0001$; Student's $t$ test; Fig. $4 a$, bottom panels).

In agreement with the substantial increase of active caspase-3 found in $\mathrm{Ddo} \mathrm{o}^{-1-}$ mice, we also detected a robust age-dependent 
a

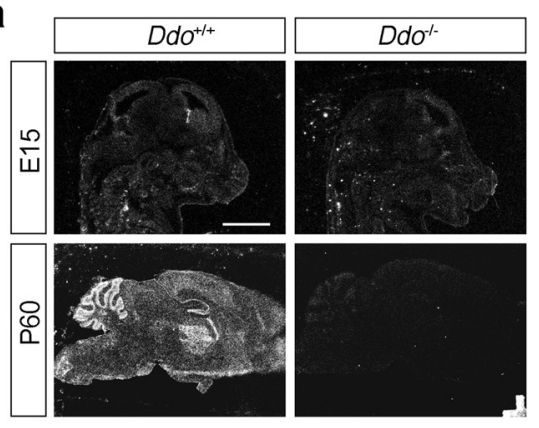

b

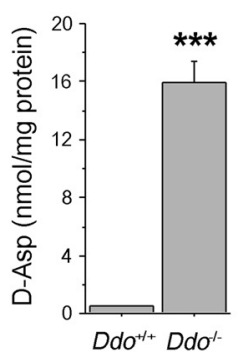

C

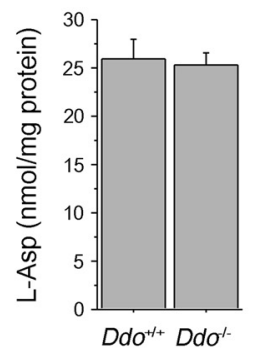

d

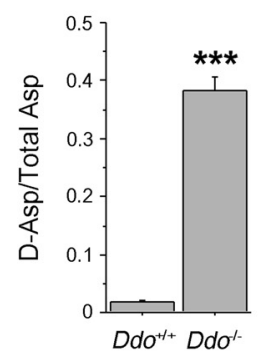

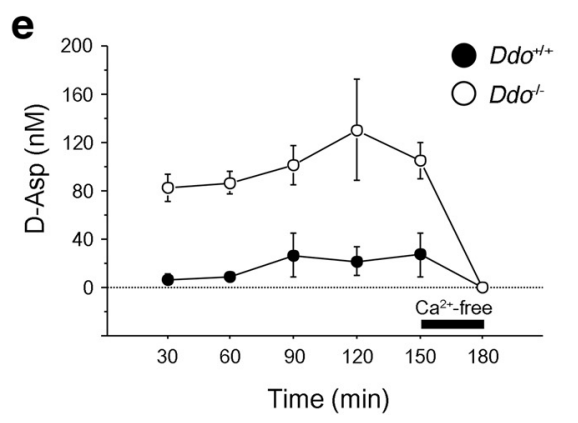

f

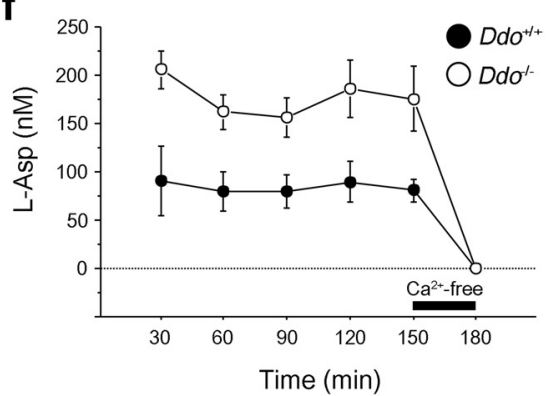

g

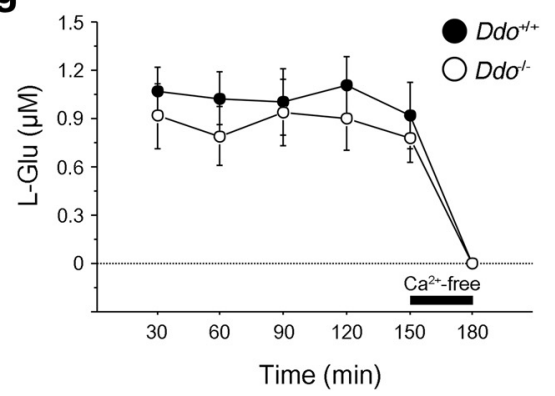

Figure 3. Increased extracellular levels of D-aspartate in the prefrontal cortex of $D d 0^{-1-}$ mice. $\boldsymbol{a}$, Representative darkfield autoradiograms of sagittal sections showing Ddo mRNA expression in the brain of $D d 0^{+/+}$and Ddo ${ }^{-/-}$mice at E15 and P60. Scale bar, $750 \mu \mathrm{m} . \boldsymbol{b}$ - $\boldsymbol{d}, \mathrm{D}$-aspartate (D-Asp) and L-aspartate (L-Asp) content in prefrontal cortex homogenates of Ddo ${ }^{+/+}$and Ddo ${ }^{-/-}$ mice $(n=5$ per genotype), measured by HPLC. The average amounts of $(\boldsymbol{b}) \mathrm{D}$-aspartate and $(\boldsymbol{c})$ L-aspartate detected during the analyses were normalized by the total protein content in the tissue samples or $(\boldsymbol{d})$ reported as D-aspartate/total aspartate ratio. ${ }^{* * *} p<0.0001$, compared with Ddo ${ }^{+/+}$mice (Student's $t$ test). $\boldsymbol{e}-\boldsymbol{g}$, Average extracellular concentration of $(\boldsymbol{e}) \mathrm{D}$-aspartate, $(\boldsymbol{f})$ L-aspartate, and $(\boldsymbol{g})$ L-glutamate (L-Glu) measured by HPLC in dialysates collected from the prefrontal cortex of freely moving Ddo ${ }^{+/+}$and Ddo ${ }^{-/-}$mice $(n=8$ for D-aspartate and L-aspartate detection, $n=5$ for $\mathrm{L}$-glutamate detection) at different time-points ( $30-180 \mathrm{~min}$ ). Last fraction of dialysates ( $150-180 \mathrm{~min}$ ) was collected in a $\mathrm{Ca}^{2+}$-free ACSF. Amino acid extracellular levels are expressed as nм (D-aspartate and L-aspartate) or $\mu \mathrm{M}$ (L-glutamate) concentration. Data are mean $\pm \mathrm{SEM}$.

activation of apoptotic events in the infralimbic/prelimbic area of these animals (genotype, $F_{(1,12)}=1157.068, p<0.0001$; genotype $\times$ age, $\left.F_{(2,12)}=286.507, p<0.0001\right)$. Indeed, subsequent post hoc analysis revealed a significantly higher percentage of TUNEL-positive cells in 6- and 13-month-old Ddo ${ }^{-1-}$ mice, compared with age-matched $D d o^{+1+}$ animals (6-month-old: $D d o^{+1+}, 27.03 \pm 1.76, D_{d o}{ }^{-1-}, 78.66 \pm 1.35 ; p<0.0001 ; 13-$ month-old: $D d o^{+/+}, 25.88 \pm 1.22, D_{d o}{ }^{-1-}, 79.29 \pm 1.01 ; p<$ 0.0001 ; Fig. $4 c, d)$.

\section{Increased levels of D-aspartate in $\mathrm{Ddo}^{-/-}$brains are associated with age-related appearance of dystrophic microglia in the substantia nigra}

We recently found that exogenous application of free D-Asp mainly triggers NMDAR-dependent currents in dopaminergic neurons of the substantia nigra pars compacta (Krashia et al., 2015). Based on this observation, we used $D d o^{-1-}$ mice to explore whether also in the SN the physiological activity of DDO is able to prevent neurotoxic insults produced by persistently elevated free D-Asp during aging.

Before starting such characterization, we first measured free D-Asp levels in the ventral midbrain of adult $D d o^{+/+}$and $D d o^{-1-}$ mice by HPLC. In line with the expression of $D d o$ in this cerebral area (Fig. $1 g$ ), we found a significant $\sim 5$-fold increase in free D-Asp content in $D d o^{-1-}$ brains, compared with controls $\left(D d o^{+/+}: 1.30 \pm 0.10 \mathrm{nmol} / \mathrm{mg}\right.$ protein, $D d o^{-/-}: 5.82 \pm 0.24$ $\mathrm{nmol} / \mathrm{mg}$ protein; $p<0.0001$, Student's $t$ test; Fig. $5 a$ ). Conversely, no significant change between genotypes was detected in free L-Asp levels $\left(D d o^{+/+}: 30.19 \pm 1.51 \mathrm{nmol} / \mathrm{mg}\right.$ protein; Ddo ${ }^{-1-}: 34.57 \pm 1.95 \mathrm{nmol} / \mathrm{mg}$ protein; $p=0.1261$; Fig. $5 b$ ). Accordingly, the D-Asp/total Asp ratio significantly increased in the midbrain of $D d o^{-/-}$animals, compared with $D d o^{+/+}$littermates $\left(D d o^{+/+}: 0.041 \pm 0.001 ; D d o^{-1-}: 0.145 \pm 0.008 ; p<\right.$ 0.0001 ; Fig. 5 c).

Then, to assess the involvement of DDO in the physiological aging process of midbrain dopaminergic neurons, we analyzed in the SN of $D d o^{-1-}$ mice the number and morphology of microglial cells (Fig. $5 d-g$ ), whose activation is considered as a reliable marker of neuronal inflammatory/neurotoxic conditions (Streit et al., 2009). To this aim, we used mice at different ages, ranging from 0.5 to 13 months. Statistical analysis revealed a significant effect of genotype on the total number of microglial cells (twoway ANOVA, $F_{(1,20)}=7.803, p=0.0002$; Fig. $5 d$ ). Subsequent post hoc analysis showed a significantly higher number of total microglia (mostly resting phenotype) in 0.5-, 3-, 10-, and 13month-old $D d o^{-1-}$ mice, compared with their respective agematched controls (0.5-month-old: $D d o^{+/+}, 1.38 \pm 0.15$ cells/ $20,000 \mu \mathrm{m}^{2} ; D d o^{-1-}, 2.76 \pm 0.30$ cells $/ 20,000 \mu \mathrm{m}^{2}, p=0.0147$; 3-month-old: $D d o^{+/+}, 1.66 \pm 0.19$ cells $/ 20,000 \mathrm{\mu m}^{2} ; D d o^{-1-}$, $3.00 \pm 0.38$ cells $/ 20,000 \mu \mathrm{m}^{2}, p=0.0366 ; 10$-month-old: Ddo ${ }^{+/+}, 2.28 \pm 0.15$ cells $/ 20,000 \mu \mathrm{m}^{2} ; \mathrm{Ddo}^{-1-}, 3.66 \pm 0.10$ cells/20,000 $\mu \mathrm{m}^{2}, p=0.0014$; 13-month-old: $D d o^{+/+}, 2.33 \pm$ 0.10 cells $/ 20,000 \mu \mathrm{m}^{2} ; D d o^{-1-}, 2.83 \pm 0.10$ cells $/ 20,000 \mu \mathrm{m}^{2}$, $p=0.0212$; Fig. $4 d$ ).

Further, we assessed the number of reactive microglia, that resulted to be differentially activated in $D d o^{+1+}$ and $D d o^{-1-}$ mice during aging (two-way ANOVA: genotype, $F_{(1,20)}=7.816$, $p=0.0112$; genotype $\times$ age, $F_{(4,20)}=3.552, p=0.0241$; Figure $5 e)$. Indeed, we found an increasing trend in the number of reactive microglia in $D d o^{-1-}$ mice at 3,6 , and 10 months of age (3-month-old: $D d o^{+/+}, 0.11 \pm 0.11$ cells $/ 20,000 \mu \mathrm{m}^{2} ; D d o^{-1-}$, $0.78 \pm 0.22$ cells $/ 20,000 \mu \mathrm{m}^{2}, p=0.055 ; 6$-month-old: $D d o^{+/+}$, 
a

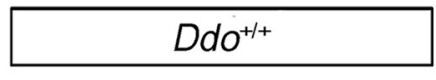

Caspase-3/DAPI
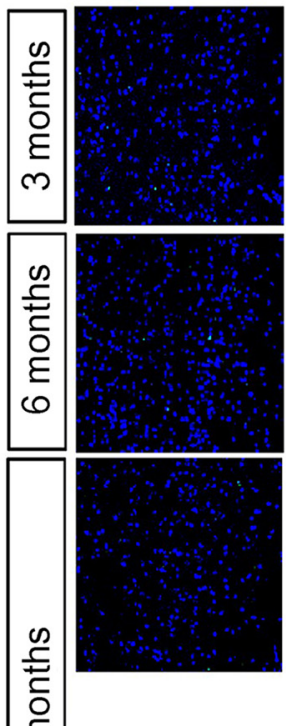

NeuN

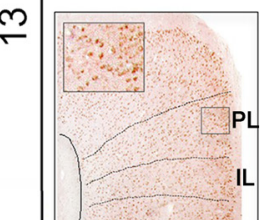

IL

Caspase-3
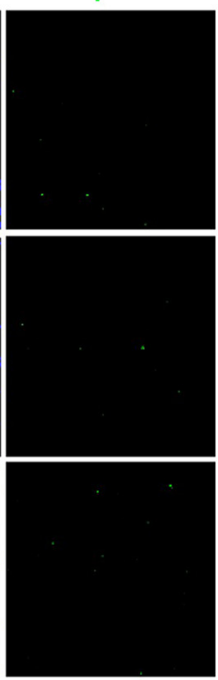

NeuN/DAPII

Caspase-3

IL
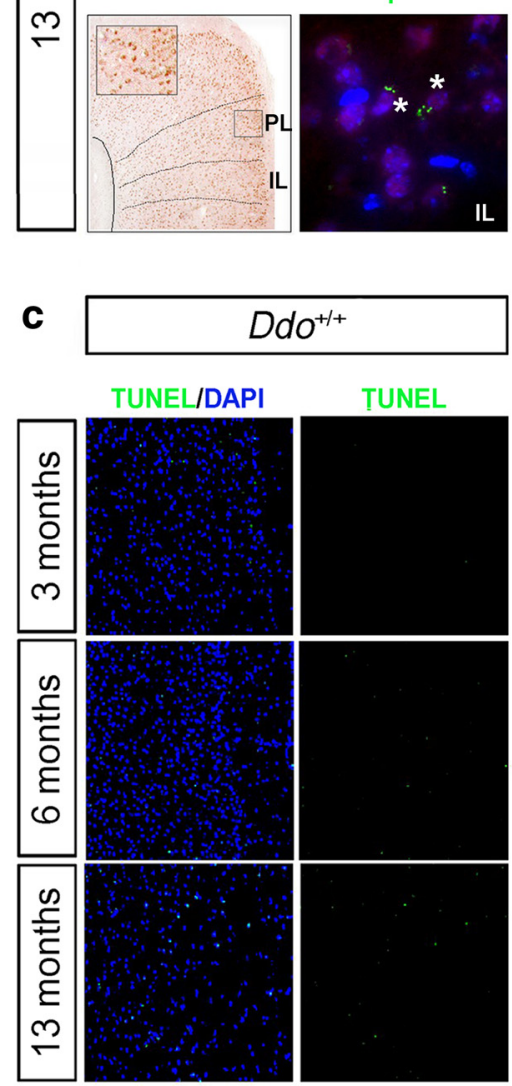

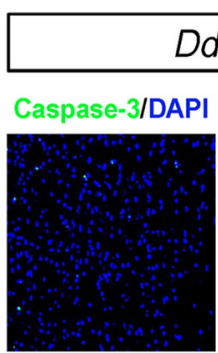

$D d o^{-1-}$
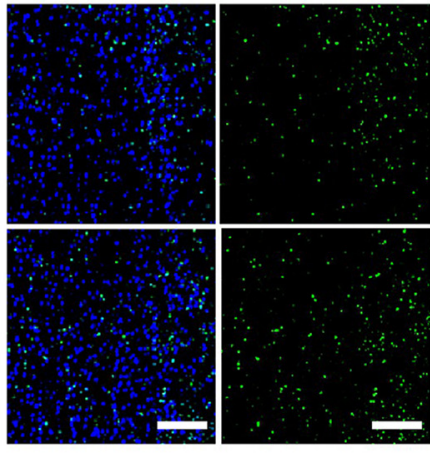

NeuN/DAPII

Caspase-3
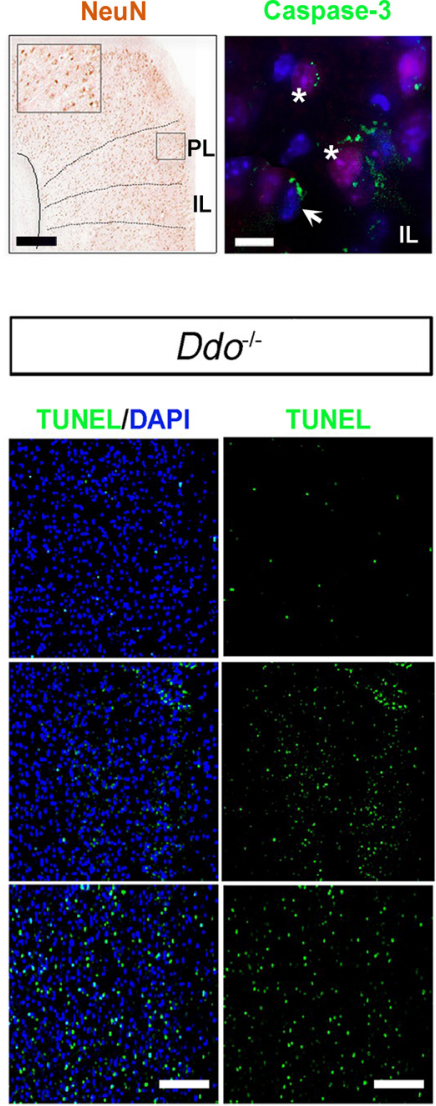

TUNEL
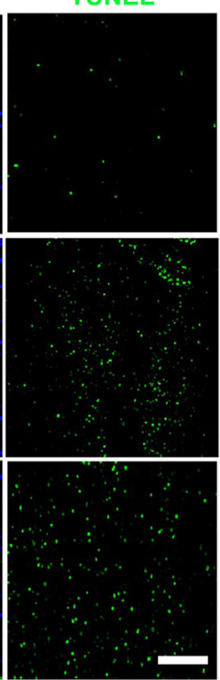

b
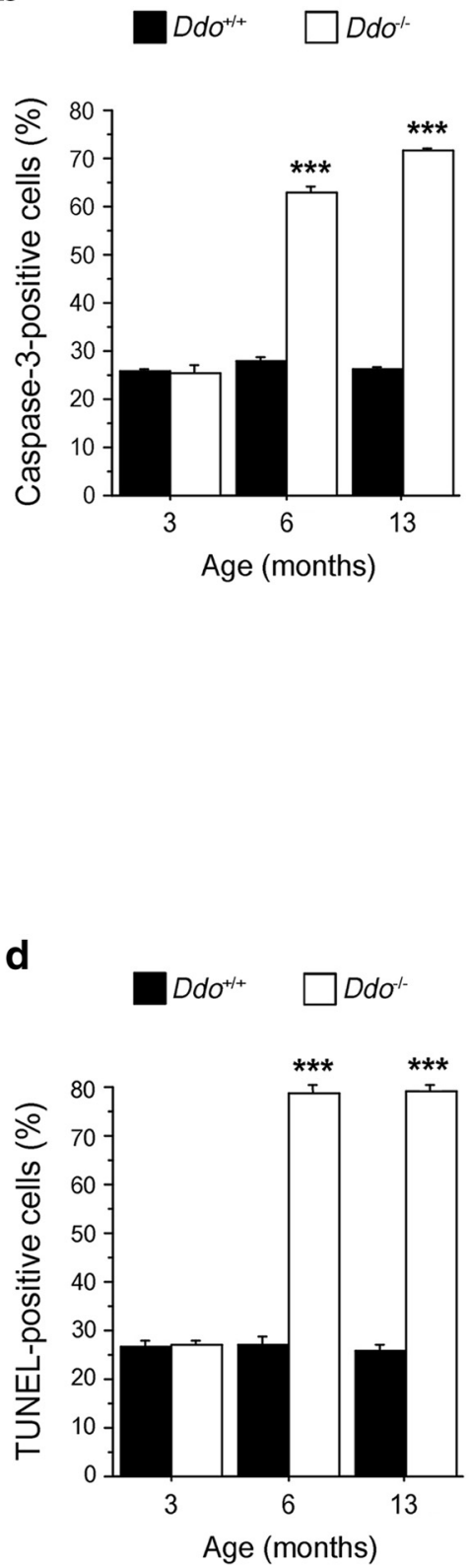

Figure 4. Precocious activation of caspase-3 and cell death in the prefrontal cortex of $D d 0^{-1-}$ mice. $\boldsymbol{a}-\boldsymbol{d}$, Analysis of apoptotic markers in pyramidal neurons of the prefrontal cortex of 3-, 6-, and 13-month-old Ddo ${ }^{+/+}$and $D d 0^{-1-}$ mice ( $n=3$ per genotype and age). $a$, Representative images showing activated caspase-3 (green) immunoreactivity in laminae II/III of the infralimbic cortex of $D d 0^{+1+}$ and $D d 0^{-1-}$ mice. Nuclei are counterstained with DAPI (blue). Bottom panels, Representative NeuN immunoperoxidase in 13 -month-old mice. Inset, High magnification of the boxed area in the prelimbic $(\mathrm{PL})$ region showing the reduction of number of NeuN-immunoreactive profiles in $D d 0^{-/-}$mice, compared with $D d 0^{+/+}$ littermates. High magnification of NeuN/DAPI/caspase-3 immunofluorescence in laminae II/III of the infralimbic (IL) cortex of 13-month-old mice. Asterisks and arrow indicate caspase-3

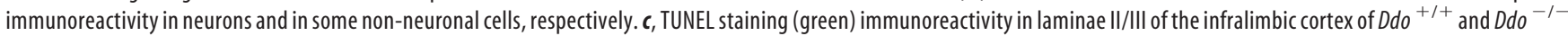
mice. Nuclei are counterstained with DAPI (blue). Scale bars: NeuN, $500 \mu \mathrm{m}$; caspase-3, caspase3/DAPI, TUNEL, TUNEL/DAPI, $100 \mu \mathrm{m}$; NeuN/DAPI/caspase-3, $8 \mu \mathrm{m}$. $\boldsymbol{b}, \boldsymbol{d}, \mathrm{Bar}$ graphs showing the percentage of $(\boldsymbol{b})$ caspase-3- and $(\boldsymbol{d})$ TUNEL-positive cells. ${ }^{* * *} p<0.0001$, compared with Ddo ${ }^{+/+}$mice (Fisher's post hoc). Data are mean \pm SEM. 
a

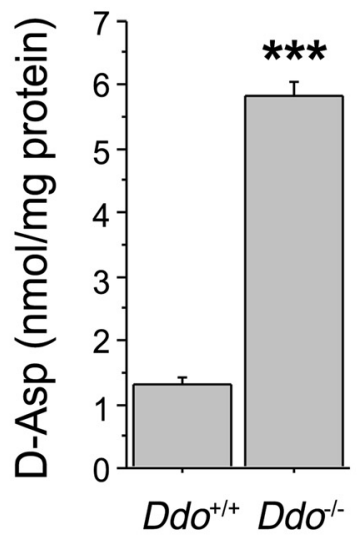

b

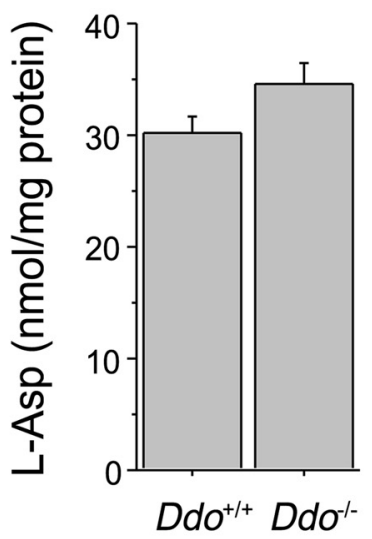

e

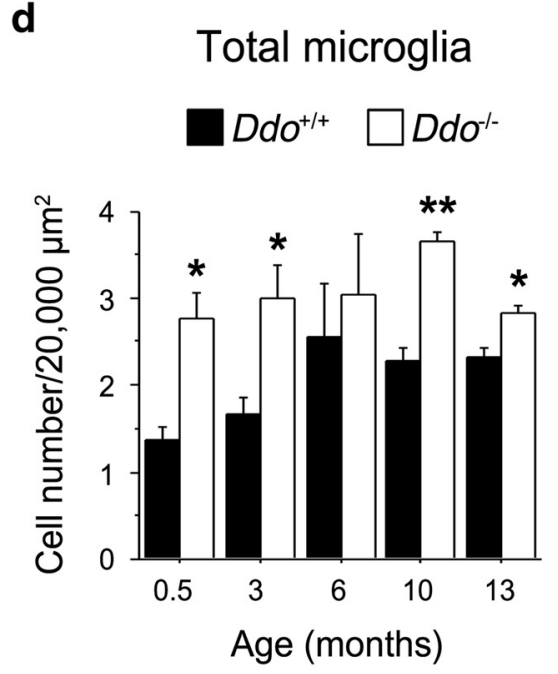

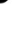

Reactive microglia

$D d o^{+/+} \square D d o^{-/}$

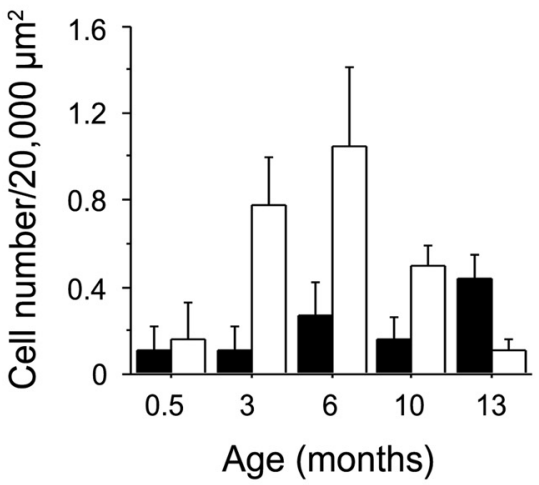

C

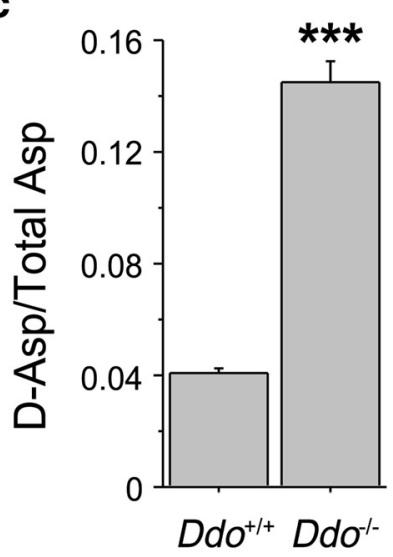

f

Dystrophic microglia

$\square \mathrm{doo^{+/+ }} \square D \mathrm{do}^{-/}$

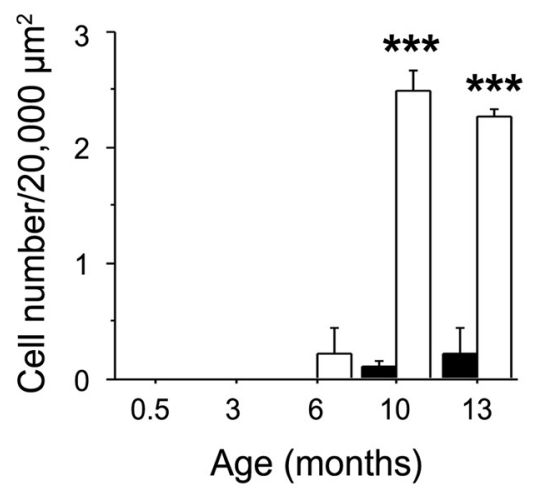

g

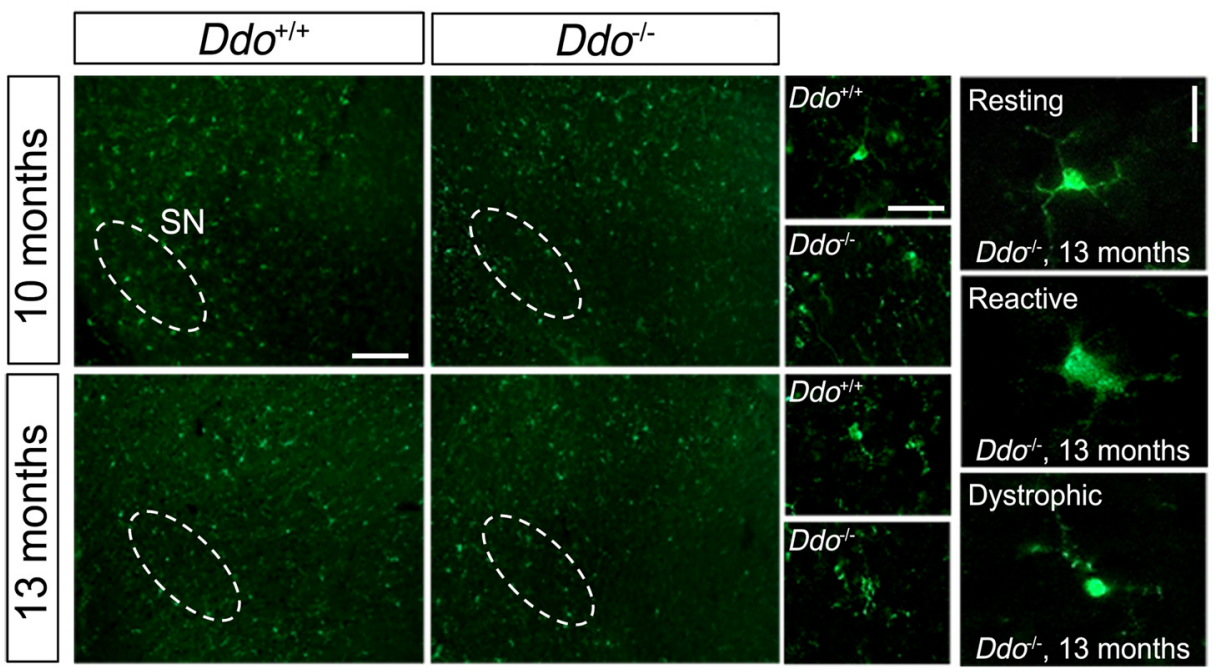

Figure 5. D-Aspartate detection in total homogenates and precocious appearance of dystrophic microglia in the midbrain of Ddo ${ }^{-/-}$mice. $\boldsymbol{a}^{-} \mathbf{C}, \mathrm{D}-$ Aspartate (D-Asp) and L-aspartate (L-Asp) content in midbrain homogenates from Ddo ${ }^{+/+}$and Ddo ${ }^{-1-}$ mice $(n=4$ per genotype), measured by HPLC analysis. The average amounts of $(\boldsymbol{a}) \mathrm{D}$-aspartate and $(\boldsymbol{b}) \mathrm{L}$-aspartate detected during the analyses were normalized by the total protein content in the tissue samples or (c) reported as the D-aspartate/total aspartate ratio. ${ }^{* * *} p<0.0001$, compared with $D d o^{+/+}$mice (Student's $t$ test). $\boldsymbol{d}-\boldsymbol{g}$, Morphological analysis of microglia in the substantia nigra of $D d 0^{+/+}$and $D d 0^{-1-}$ mice during ontogenesis ( $n=3$ per genotype and age), evaluated by Iba- 1 immunofluorescence. Quantitative analysis of the $(\boldsymbol{d})$ total, $(\boldsymbol{e})$ hypertrophic, and $(\boldsymbol{f})$ dystrophic-like microglia at $0.5,3,6,10$, and 13 months of age. $\boldsymbol{g}$, Immunofluorescence of Iba-1-positive microglial cells in the substantia nigra of 10 - and 13 -month-old $D d 0^{+/+}$and $D d 0^{-1-}$. At the lowest magnification, the region of the substantia nigra is delimited by a dotted oval. At the highest magnification, examples are shown of resting, reactive, and dystrophic-like microglia identified in the substantia nigra of 13 -month-old $D d 0^{-/-}$mice. Scale bars: $200,50,25 \mu$ m. ${ }^{*} p<0.05$, compared with $D d 0^{+/+}$mice (Fisher's post hoc). ${ }^{* *} p<0.01$, compared with Ddo ${ }^{+/+}$mice (Fisher's post hoc). ${ }^{* * *} p<0.0001$, compared with Ddo ${ }^{+/+}$mice (Fisher's post hoc). Data are mean \pm SEM. 
$0.27 \pm 0.15$ cells $/ 20,000 \mu \mathrm{m}^{2} ; D d o^{-1-}, 1.05 \pm 0.36$ cells $/ 20,000$ $\mu \mathrm{m}^{2}, p=0.1186$; 10-month-old: $D d o^{+/+}, 0.16 \pm 0.09$ cells/ $20,000 \mu \mathrm{m}^{2} ; D d o^{-1-}, 0.50 \pm 0.10$ cells $/ 20,000 \mu \mathrm{m}^{2}, p=0.0700$; Fig. 5e) and, conversely, a trend decline in 13-month-old knockouts, compared with wild-type littermates $\left(D d o^{+/+}, 0.44 \pm 0.11\right.$ cells/20,000 $\mathrm{\mu m}^{2} ; D d o^{-1-}, 0.11 \pm 0.06$ cells $/ 20,000 \mu \mathrm{m}^{2}, p=$ 0.0550; Fig. 5e).

Finally, we counted the number of dystrophic microglia, characterized by fragmented cell body and processes, which is thought to be predictive of neuronal damage, as reported also in Alzheimer's disease human brain (Streit et al., 2009). Consistent with the neurotoxic effect of deregulated D-Asp levels, we found an age-related appearance of dystrophic microglia in the SN of $D d o^{-1-}$ mice, which was not detected in $\mathrm{Ddo}{ }^{+/+}$controls (twoway ANOVA: age, $F_{(4,20)}=70.502, p<0.0001$; genotype, $F_{(1,20)}=$ 165.302, $p<0.0001$; age $\times$ genotype, $F_{(4,20)}=53.456, p<$ 0.0001 ; Figure $5 f$ ). In particular, we evidenced a significant occurrence of dystrophic microglia specifically in 10- and 13month-old $D d o^{-1-}$ mice, compared with their respective agematched controls (10-month-old: Ddo ${ }^{+/+}, 0.11 \pm 0.05$ cells/ $20,000 \mu \mathrm{m}^{2} ; D d o^{-l-}, 2.50 \pm 0.17$ cells $/ 20,000 \mu \mathrm{m}^{2}, p=0.0002$; 13-month-old: $D d o^{+/+}, 0.22 \pm 0.22$ cells $/ 20,000 \mu \mathrm{m}^{2} \mathrm{Ddo}{ }^{-/-}$, $2.27 \pm 0.06$ cells $/ 20,000 \mu \mathrm{m}^{2}, p=0.0009$; Fig. 5f,g).

\section{Increased levels of free $\mathrm{D}$-aspartate trigger age-related caspase- 3 activation and cell death in dopaminergic neurons of the substantia nigra}

Based on the abnormal appearance of dystrophic microglia, we explored whether the constitutive upregulation of free D-Asp levels in $D d o^{-1-}$ brains also triggered the activation of apoptotic pathway and cell death in TH-positive neurons of the SN. To this aim, we evaluated the expression levels of active caspase- 3 in $0.5-$, 3-, 6-, 10-, and 13-month-old Ddo ${ }^{-1-}$ mice. Interestingly, we found a significant genotype-dependent variation in the percentage of active caspase-3-positive cells (two-way ANOVA: genotype, $F_{(1,20)}=214.010, p<0.0001$; age $\times$ genotype, $F_{(4,20)}=$ 22.902, $p<0.0001)$. Accordingly, post hoc analysis revealed a higher expression of active caspase-3 already in 3-month-old and, more substantially, also in 6-, 10-, and 13-month-old knockout animals, compared with their respective age-matched controls (3-month-old: $D d o^{+/+}, 14.16 \pm 1.12 \%, D d o^{-1-}, 18.40 \pm$ $0.81 \%, p=0.0375$; 6-month-old: $D d o^{+/+}, 18.57 \pm 1.45 \%$, Ddo ${ }^{-1-}, 36.66 \pm 2.35 \%, p=0.0028 ; 10$-month-old: $D d o^{+/+}$, $19.99 \pm 2.05 \%, D_{d o}{ }^{-1-}, 45.42 \pm 0.50 \%, p=0.0003$; 13 -monthold: $D d o^{+/+}, 19.34 \pm 2.47 \%, D d o^{-1-}, 49.52 \pm 2.41 \%, p=$ 0.0009 ; Fig. $6 a, b$, arrows).

Finally, we detected TUNEL staining in the SN of 3-, 6-, and 13 -month-old $D d^{-1-}$ mice. In agreement with previous results found in the PFC, we revealed that the number of TUNEL/THpositive neurons in this brain region of $D d o^{-1-}$ mice significantly increased with age (two-way ANOVA: genotype, $F_{(1,12)}=214.764$, $p<0.0001$; genotype $\times$ age, $\left.F_{(2,12)}=44.238, p<0.0001\right)$. The following post hoc analysis showed a higher percentage of positive cells in 6- and 13-month-old Ddo ${ }^{-1-}$ mice, compared with agematched controls (6-month-old: $D d o^{+/+}, 21.28 \pm 1.06, D d o^{-1-}$, $41.65 \pm 1.16, p=0.0002$; 13 -month-old: $D d o^{+/+}, 21.83 \pm 0.93$, $D d o^{-1-}, 47.93 \pm 1.75, p=0.0002$; Fig. $\left.6 c, d\right)$.

Overall, our data indicate that physiological enzymatic activity of DDO in the brain has a relevant neuroprotective effect able to prevent abnormal accumulation of extracellular free D-Asp that would otherwise trigger precocious degenerative events during aging.

\section{Increased extracellular levels of free D-aspartate elicit} precocious age-related accumulation of lipofuscin in $\mathrm{Ddo}$ brains

To investigate the presence of oxidative stress as a consequence of persistent upregulation of free D-Asp levels, we assessed in Ddo ${ }^{-1-}$ mice the levels of lipofuscin deposition, an autofluorescent pigment that accumulates over time and that positively correlates with the rate of aging (Brunk and Terman, 2002; Riga et al., 2006). Interestingly, lipofuscin accumulation was not yet detectable either in the SN (Fig. 7a) or in the PFC (data not shown) of both genotypes at preweaning stage ( 0.5 months). Conversely, in both the SN and in the layers V-VI of the PFC of adult $D d o^{-1-}$ animals (3 months), we observed a significant increase of the total volume of lipofuscin inclusion bodies compared with $D d o^{+/+}$mice (Fig. $7 a, b ; p<0.05$, Student's $t$ test). The precocious accumulation of lipofuscin in the $D d o^{-/-}$brain suggests that persistent elevation of D-Asp levels triggers greater oxidative stress and further supports the role of aberrant D-Asp metabolism on the early neurodegenerative events found in mutants.

\section{Discussion}

In the present work, we first demonstrated conserved age-related reduction of free $\mathrm{D}$-Asp levels in the mouse brain, in line with previous observations in rats and humans (Hashimoto et al., 1993; Schell et al., 1997; Sakai et al., 1998; Wolosker et al., 2000). In addition, we showed a remarkable age-related increase in Ddo mRNA levels that is in line with the previously reported postnatal enhancement in DDO activity (Van Veldhoven et al., 1991) and the progressive decrease in free D-Asp levels. This evidence suggests that the ontogenetic changes in Ddo mRNA expression are most likely able to control, as net effect, the actual concentration of free D-Asp in the brain. Consistently, we have recently found that reduced levels of free D-Asp in the PFC of patients with schizophrenia (Errico et al., 2013) are associated with increased levels of Ddo mRNA, compared with healthy subjects (Errico et al., 2015b). Interestingly, we also found that the temporal increase in postnatal Ddo mRNA levels is mirrored by a concomitant and progressive demethylation of Ddo gene regulatory region surrounding the TSS. To unveil the causal relationship between demethylation of the putative Ddo promoter and increased Ddo transcription, we tested the effect of the DNAdemethylating agent azacitidine in primary neuronal culture from embryonic brain, when the physiological expression of this gene is nearly undetectable. Interestingly, the evidence that azacitidine induces an $\sim 4$-fold increase in Ddo mRNA levels, compared with vehicle-treated controls, indicates the existence of a finely tuned demethylation process at the basis of the observed postnatal increase in $D d o$ gene expression. In this view, we argue that the epigenetic changes within the $D d o$ regulatory region herein investigated are part of a developmental program to regulate the timed expression of the Ddo gene during prenatal and postnatal brain development. On the other hand, ISH clearly indicated that postnatal transcriptional activation of Ddo gene differs from one brain area to another, suggesting that $D d o$ promoter demethylation occurs with a peculiar spatiotemporal pattern to properly regulate the regional postnatal occurrence of DDO and, ultimately, free D-Asp concentrations.

Despite pharmacological, neurophysiological, and behavioral data indirectly asserting a role for free D-Asp in modulating glutamatergic system (Errico et al., 2012, 2015a), the basal cerebral content of this D-amino acid has long been considered too low to justify a neurobiological implication at adulthood. Herein, by 
a
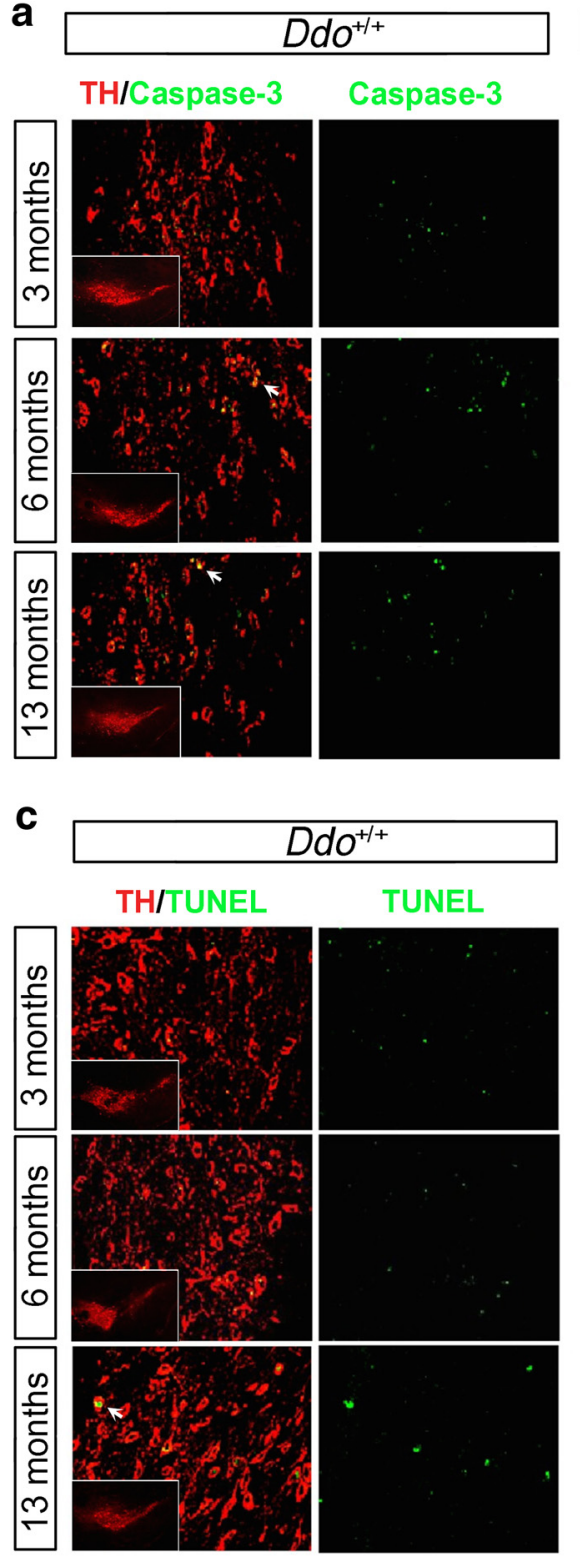
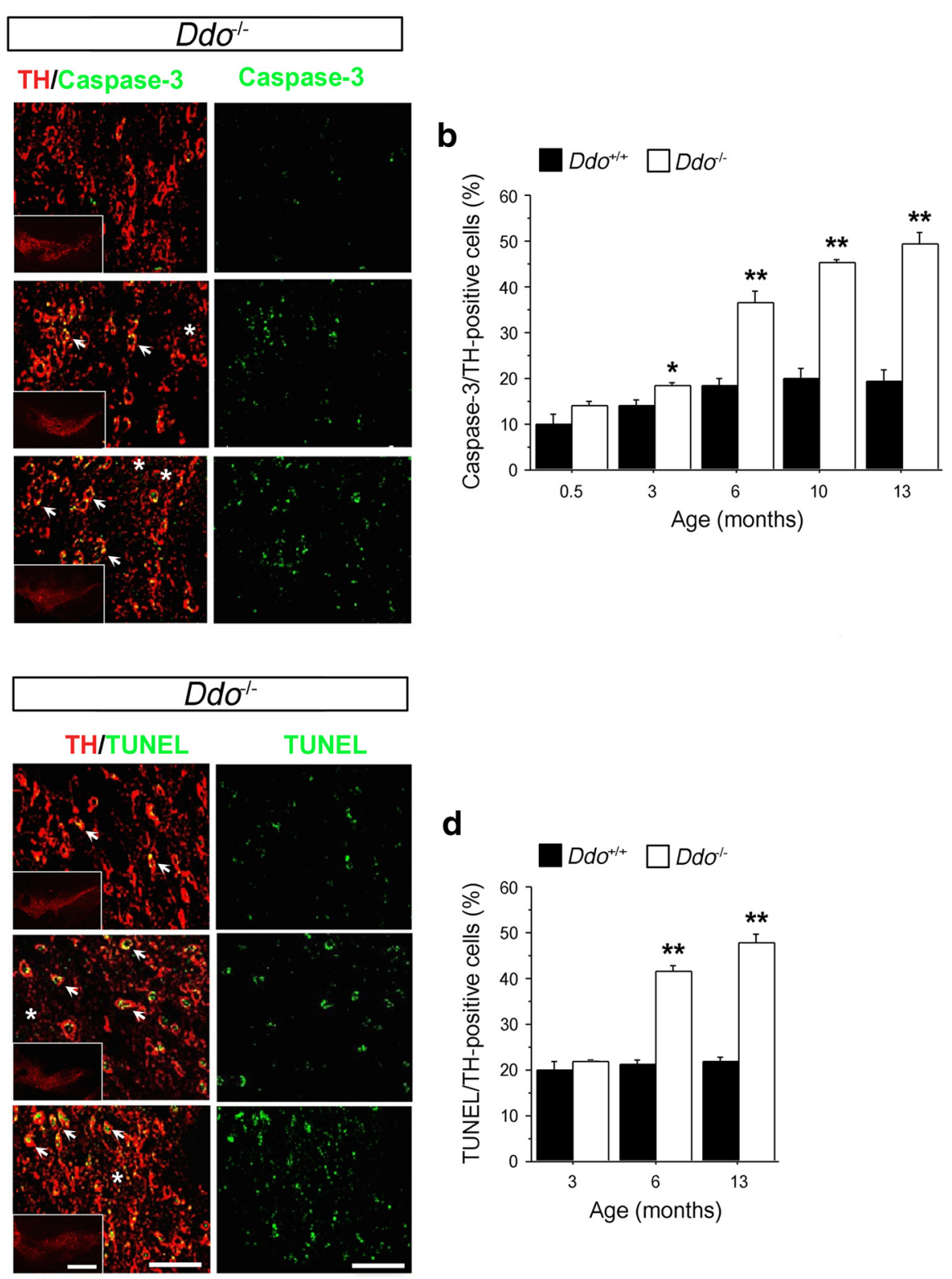

d

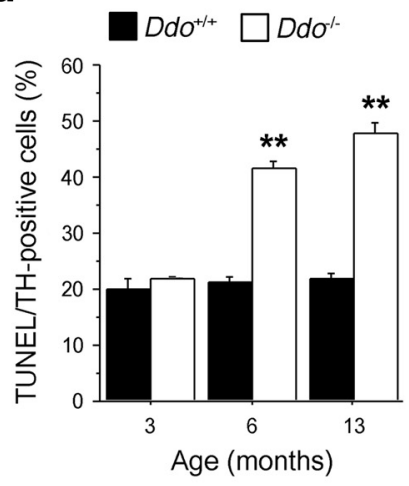

Figure 6. Precocious activation of caspase- 3 and cell death in the substantia nigra of $D d 0^{-/-}$mice. $\boldsymbol{a}-\boldsymbol{d}$, Analysis of apoptotic markers in TH-positive neurons of the substantia nigra of $D d 0^{+/+}$ and $D d o^{-1-}$ mice during ontogenesis $(n=3$ per genotype and age). $\boldsymbol{a}, \boldsymbol{c}$, Representative images showing (a) activated caspase-3 immunoreactivity or (c) TUNEL staining immunoreactivity in TH-positive neurons from 3-, 6-, and 13-month-old $D d 0^{+/+}$and $D d 0^{-1-}$ mice ( $n=3$ per genotype and age). Arrows indicate some of these neurons. Asterisks indicate representative areas, including TH-positive neuronal apoptotic debris. Insets, Low magnifications of the substantia nigra showing a significant reduction of TH immunodensity in Ddo ${ }^{-/-}$, compared with Ddo $^{+/+}$mice, more evident in aged Ddo ${ }^{-1-}$ mice. Scale bars: insets, $200 \mu \mathrm{m}$; TH/caspase-3, caspase-3, TH/TUNEL, TUNEL, $50 \mu \mathrm{m} . \boldsymbol{b}, \boldsymbol{d}$, Bar graphs represent the percentage of (b) caspase-3/TH-positive cells (0.5-, 3-, 6-, 10-, and 13-month-old Ddo ${ }^{+/+}$and Ddo ${ }^{-/-}$mice) or (d) TUNEL/TH-positive cells (3-, 6-, and 13-month-old Ddo ${ }^{+/+}$and Ddo ${ }^{-/-}$mice). ${ }^{*} p<0.05$, compared with Ddo ${ }^{+/+}$mice (Fisher's post hoc). ${ }^{* *} p<0.01$, compared with Ddo ${ }^{+/+}$mice (Fisher's post hoc). Data are mean \pm SEM.

means of microdialysis studies performed in the PFC of freely moving animals, we demonstrated the occurrence of nanomolar concentrations of extracellular free D-Asp in controls $(\sim 20 \mathrm{nM})$ and, most interestingly, an increase of $\sim 5$ times of this D-amino acid content in knock-out mice. Moreover, in agreement with previous in vitro studies (Davies and Johnston, 1976; MaltheSørenssen et al., 1979; Nakatsuka et al., 2001; Savage et al., 2001; Raiteri et al., 2007; D'Aniello et al., 2011), we found that endogenous free D-Asp is released also in vivo by neurons through a $\mathrm{Ca}^{2+}$-dependent mechanism, as extracellular concentration of this D-amino acid is below the detection limit in $\mathrm{Ca}^{2+}$-free condition. Unexpectedly, we also detected increased extracellular L-Asp levels in $D d o^{-I-}$ mice but unchanged total content of the
L-isomer, as reported also in other studies (Errico et al., 2006; Han et al., 2015). In the attempt to explain such an interesting result, we hypothesize that exaggerated intracellular accumulation of free D-Asp may locally alter the racemization rate of D-Asp to L-Asp in the cortical nerve terminals and/or affect the mechanism of L-Asp release and uptake. Unlike extracellular D-Asp and L-Asp, we did not find any difference in the extracellular levels of L-Glu detected in the PFC of $\mathrm{Ddo}^{+/+}$and $D d o^{-1-}$ mice. However, as shown for free D-Asp, the release of both L-Asp and L-Glu was suppressed in dialysates without $\mathrm{Ca}^{2+}$. Although this effect is expected for classical neurotransmitters, the in vivo evidence of free D-Asp clearance suggests that this D-amino acid can be actively and efficiently removed from the extracellular space, likely 


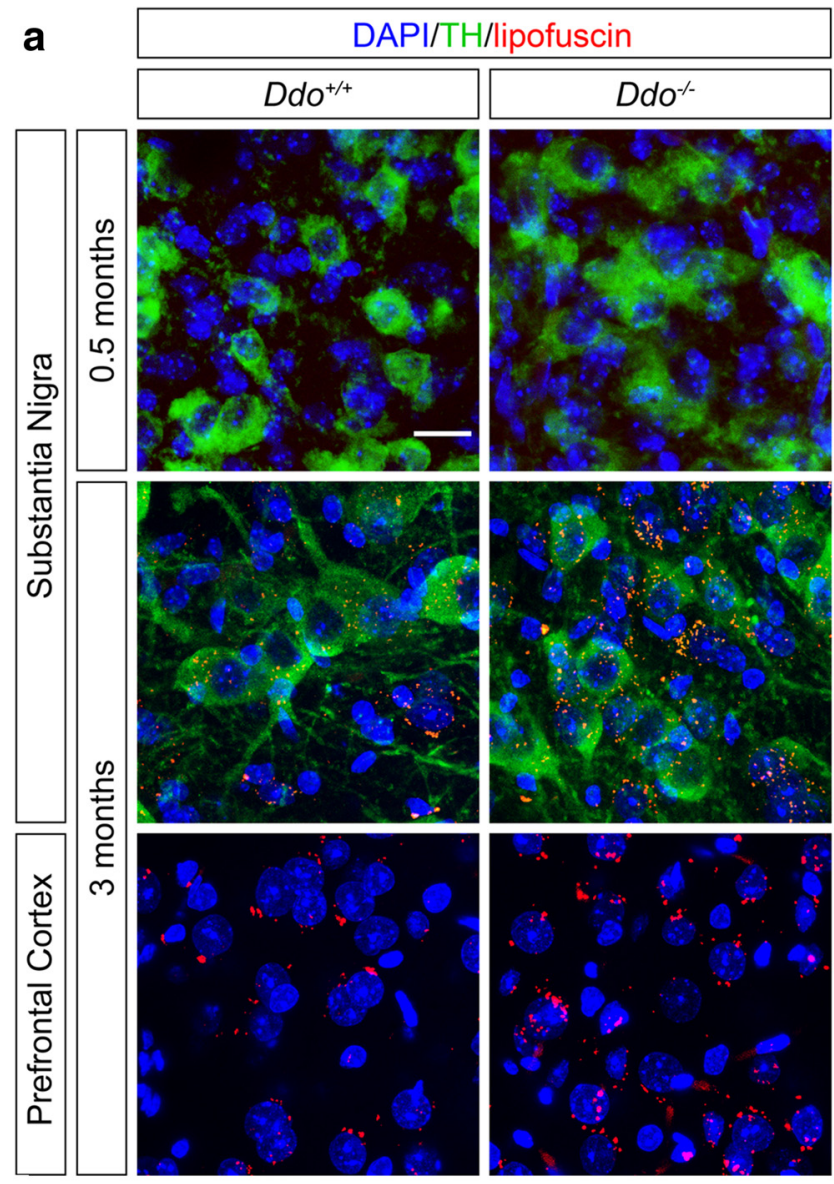

b

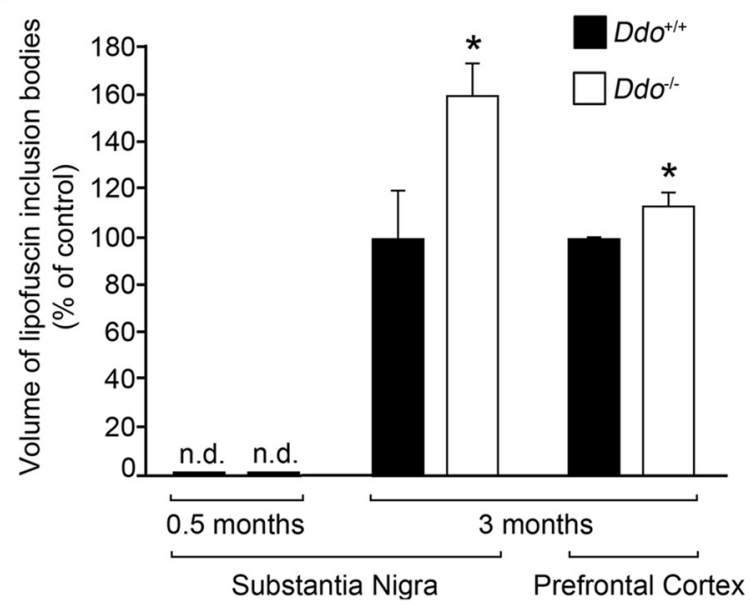

Figure 7. Increased age-dependent lipofuscin accumulation in the substantia nigra pars compacta and prefrontal cortex of $D d 0^{-1-}$ mice. $\boldsymbol{a}$, Representative high-magnification confocal images of the substantia nigra pars compacta and prefrontal cortex (layers V-VI) of Ddo ${ }^{+/+}$ and $D d 0^{-1-}$ mice at 0.5 and 3 months of age ( $n=3$ per genotype and age). Higher accumulation of lipofuscin granules (red) appears evident in 3-month-old Ddo ${ }^{-1-}$ compared with $\mathrm{Ddo}^{+/+}$specimens in both TH-immunostained (green) dopaminergic neurons as well as in deep layers (V-VI) of the prefrontal cortex. $\boldsymbol{b}$, Quantification of lipofuscin inclusion bodies volume in the substantia nigra and prefrontal cortex. Data are mean \pm SEM. n.d., Nondetectable. ${ }^{*} p<0.05$, compared with Ddo ${ }^{+/+}$mice (Student's $t$ test). Scale bar, $5 \mu \mathrm{m}$.

through L-Glu/L-Asp transport system, which has been previously shown to mediate the in vitro uptake of both Asp enantiomers approximately with the same affinity (Arriza et al., 1994, 1997; Palacín et al., 1998).
Despite that the existence of enzymes catalyzing the degradation of D-amino acids is long established (Krebs, 1935), the role of DDO in the brain has been puzzling because of the negligible levels of its endogenous substrates. Importantly, herein we report that DDO exerts its physiological role by protecting the brain from the neurotoxic effects induced by persistently higher extracellular levels of its substrate, D-Asp, known to act as an NMDAR agonist. Indeed, consistent with the knowledge that sustained overactivation of NMDARs at extrasynaptic sites is detrimental for neuronal survival (Lipton, 2008; Hardingham and Bading, 2010; Parsons and Raymond, 2014), we showed that the lack of DDO in knock-out mice, through the resulting persistent spillover of extracellular D-Asp, triggers precocious oxidative stress, activation of caspase-3, and cell death in the PFC and SN. Interestingly, coexpression of activated caspase- 3 with NeuN in the $\mathrm{PFC}$, and with $\mathrm{TH}$ in the $\mathrm{SN}$, demonstrates that cell death in these brain areas of $D d o^{-1-}$ mice involves pyramidal and dopaminergic neurons, respectively. On the other side, active caspase-3 immunoreaction is also, to some extent, detected outside NeuNand TH-positive neurons, thus suggesting that apoptotic events triggered by increased D-Asp levels are not exclusive of these cell types.

Previous findings have demonstrated that D-Asp is the best substrate for human and mouse DDO, followed by NMDA (Setoyama and Miura, 1997; Katane et al., 2015a). Indeed, the mouse enzyme is also active on D-Glu and D-asparagine, but the relative activity is only $3.7 \%$ and $1.3 \%$ of the one determined for D-Asp (no activity was instead detected on D-histidine and other D-amino acids). Accordingly, it is conceivable that the activity of mouse DDO is too low to affect the cellular levels of these alternative substrates that, in turn, cannot contribute to the phenotypes observed in $\mathrm{Ddo} \mathrm{o}^{-1-}$ mice. In addition to D-Asp, we have previously reported increased endogenous levels of NMDA in brain $D d o^{-1-}$ homogenates. However, the content of NMDA in knock-out brains is hundreds-fold lower than D-Asp (Errico et al., 2006, 2011c). Therefore, we think that the contribution of this molecule to the overstimulation of NMDARs in Ddo ${ }^{-1-}$ brain is likely negligible compared with that produced by the massive accumulation of free D-Asp.

Neurodegenerative events in knock-out mice are accompanied by substantial changes in microglia morphology. Indeed, we found in the SN an age-dependent phenotypic shift of microglia from hypertrophic toward a dystrophic one. This could be explained assuming that, in an early stage (3, 6 months), reactive microglia are in charge with the removal of high caspase-3positive apoptotic cells, including clusters of lipopigments, such as lipofuscin (Riga et al., 2006), thus becoming overloaded and dystrophic in a late phase (10, 13 months). Strikingly, the observation of dystrophic microglia in a mouse model is quite a rare finding because this kind of cell does not appear with aging in rodents, as they do in humans during aging and in aging-related neurodegenerative disorders, including Alzheimer's disease (Streit and Xue, 2014; Streit et al., 2014).

Together, these data are coherent with previous morphological, functional, and in vivo observations indicating that constitutively upregulated levels of D-Asp in aged (6-month-old onwards) $D d o^{-1-}$ mice lead to the progressive decay of synaptic transmission and plasticity, ERK signaling, cognitive abilities, and increased sensitivity to phencyclidine-induced prepulse inhibition deficit (Errico et al., 2011b; Cristino et al., 2015). Conversely, higher free D-Asp content in young-adult $D d o^{-1-}$ mice has beneficial NMDAR-mediated effects because it enhances hippocampal early- and late-phase LTP (Errico et al., 2008b, 2011b, 
2014), ERK phosphorylation (Errico et al., 2011b), and dendritic length and spine density (Errico et al., 2014), ameliorates spatial memory (Errico et al., 2008a, 2011b), and reduces prepulse inhibition deficits produced by psychotomimetic drugs, such as amphetamine, MK801, and phencyclidine (Errico et al., 2008a, $2015 b)$. The opposite phenotypes shown by $D d o^{-/-}$mice at different phases of postnatal life highlight the peculiarity of this animal model to reproduce the dichotomous behavior of NMDAR signaling, which is able to promote synaptic plasticity and cognition or excitotoxicity depending on the subcellular localization (synaptic vs extrasynaptic activation). Further studies are needed to investigate how constitutive increase of free D-Asp can trigger synaptic or extrasynaptic NMDAR signaling in a timedependent manner.

Notably, the abnormal precocious cell death produced by constitutively elevated free D-Asp levels in Ddo ${ }^{-1-}$ brains suggests that DDO may control the vulnerability to neurodegeneration by hindering the endogenous accumulation of its substrate. Conversely, the physiological abundance of free D-Asp in the embryonic and perinatal brain, due to negligible $D$ do expression and enzyme activity (Van Veldhoven et al., 1991), indicates that the physiological role of D-Asp must be restricted to a limited developmental time window, after which its high content would be harmful. In this regard, it is mandatory that the generation of conditional $\mathrm{Ddo} \mathrm{o}^{-1-}$ mice and the employment of inhibitors for DDO enzyme (Katane et al., 2015b) to test the safety of transient D-Asp increase (as opposed to the detrimental effects of its persistent elevation) in the adult brain.

In conclusion, our results show, for the first time, that the progressive demethylation of the putative Ddo promoter is the mechanism for the postnatal onset and subsequent increase of Ddo expression that, in turn, is critical to regulate the content of the NMDAR agonist, D-Asp, in adulthood. In a mouse model with constitutively suppressed $D d o$ expression, we demonstrated that deregulated extracellular levels of D-Asp are able to produce early oxidative stress and cell death, thus unmasking a key role for DDO in counteracting precocious neurodegeneration produced by excessive NMDAR stimulation. In this light, $D d o^{-1-}$ mice represent a novel animal model of accelerated brain aging deterioration with potential application for in vivo screening of antiaging compounds.

\section{References}

Arriza JL, Fairman WA, Wadiche JI, Murdoch GH, Kavanaugh MP, Amara SG (1994) Functional comparisons of three glutamate transporter subtypes cloned from human motor cortex. J Neurosci 14:5559-5569. Medline

Arriza JL, Eliasof S, Kavanaugh MP, Amara SG (1997) Excitatory amino acid transporter 5 , a retinal glutamate transporter coupled to a chloride conductance. Proc Natl Acad Sci U S A 94:4155-4160. CrossRef Medline

Bifulco D, Pollegioni L, Tessaro D, Servi S, Molla G (2013) A thermostable L-aspartate oxidase: a new tool for biotechnological applications. Appl Microbiol Biotechnol 97:7285-7295. CrossRef Medline

Brunk UT, Terman A (2002) Lipofuscin: mechanisms of age-related accumulation and influence on cell function. Free Radic Biol Med 33:611-619. CrossRef Medline

Cristino L, Luongo L, Squillace M, Paolone G, Mango D, Piccinin S, Zianni E, Imperatore R, Iannotta M, Longo F, Errico F, Vescovi AL, Morari M, Maione S, Gardoni F, Nisticò R, Usiello A (2015) D-Aspartate oxidase influences glutamatergic system homeostasis in mammalian brain. Neurobiol Aging 36:1890-1902. CrossRef Medline

D'Aniello A, Vetere A, Petrucelli L (1993) Further study on the specificity of D-amino acid oxidase and D-aspartate oxidase and time course for complete oxidation of D-amino acids. Comp Biochem Physiol 105:731-734. Medline

D’Aniello S, Somorjai I, Garcia-Fernàndez J, Topo E, D’Aniello A (2011)
D-Aspartic acid is a novel endogenous neurotransmitter. FASEB J 25: 1014-1027. CrossRef Medline

Davies LP, Johnston GA (1976) Uptake and release of D-and L-aspartate by rat brain slices. J Neurochem 26:1007-1014. CrossRef Medline

Dunlop DS, Neidle A, McHale D, Dunlop DM, Lajtha A (1986) The presence of free D-aspartic acid in rodents and man. Biochem Biophys Res Commun 141:27-32. CrossRef Medline

Errico F, Pirro MT, Affuso A, Spinelli P, De Felice M, D’Aniello A, Di Lauro R (2006) A physiological mechanism to regulate D-aspartic acid and NMDA levels in mammals revealed by D-aspartate oxidase deficient mice. Gene 374:50-57. CrossRef Medline

Errico F, Rossi S, Napolitano F, Catuogno V, Topo E, Fisone G, D'Aniello A, Centonze D, Usiello A (2008a) D-Aspartate prevents corticostriatal long-term depression and attenuates schizophrenia-like symptoms induced by amphetamine and MK801. J Neurosci 28:10404-10414. CrossRef Medline

Errico F, Nisticò R, Palma G, Federici M, Affuso A, Brilli E, Topo E, Centonze D, Bernardi G, Bozzi Y, D’Aniello A, Di Lauro R, Mercuri NB, Usiello A (2008b) Increased levels of D-aspartate in the hippocampus enhance LTP but do not facilitate cognitive flexibility. Mol Cell Neurosci 37:236-246. CrossRef Medline

Errico F, Nisticò R, Napolitano F, Mazzola C, Astone D, Pisapia T, Giustizieri M, D’Aniello A, Mercuri NB, Usiello A (2011a) Increased D-aspartate brain content rescues hippocampal age-related synaptic plasticity deterioration of mice. Neurobiol Aging 32:2229-2243. CrossRef Medline

Errico F, Nisticò R, Napolitano F, Oliva AB, Romano R, Barbieri F, Florio T, Russo C, Mercuri NB, Usiello A (2011b) Persistent increase of D-aspartate in D-aspartate oxidase mutant mice induces a precocious hippocampal age-dependent synaptic plasticity and spatial memory decay. Neurobiol Aging 32:2061-2074. CrossRef Medline

Errico F, Bonito-Oliva A, Bagetta V, Vitucci D, Romano R, Zianni E, Napolitano F, Marinucci S, Di Luca M, Calabresi P, Fisone G, Carta M, Picconi B, Gardoni F, Usiello A (2011c) Higher free D-aspartate and N-methyl-Daspartate levels prevent striatal depotentiation and anticipate L-DOPAinduced dyskinesia. Exp Neurol 232:240-250. CrossRef Medline

Errico F, Napolitano F, Nisticò R, Usiello A (2012) New insights on the role of free D-aspartate in the mammalian brain. Amino Acids 43:1861-1871. CrossRef Medline

Errico F, Napolitano F, Squillace M, Vitucci D, Blasi G, de Bartolomeis A, Bertolino A, D'Aniello A, Usiello A (2013) Decreased levels of d-aspartate and NMDA in the prefrontal cortex and striatum of patients with schizophrenia. J Psychiatr Res 47:1432-1437. CrossRef Medline

Errico F, Nisticò R, Di Giorgio A, Squillace M, Vitucci D, Galbusera A, Piccinin S, Mango D, Fazio L, Middei S, Trizio S, Mercuri NB, Teule MA, Centonze D, Gozzi A, Blasi G, Bertolino A, Usiello A (2014) Free D-aspartate regulates neuronal dendritic morphology, synaptic plasticity, gray matter volume and brain activity in mammals. Transl Psychiatry 4:e417. CrossRef Medline

Errico F, Mothet JP, Usiello A (2015a) D-Aspartate: an endogenous NMDA receptor agonist enriched in the developing brain with potential involvement in schizophrenia. J Pharm Biomed Anal 116:7-17. CrossRef Medline

Errico F, D’Argenio V, Sforazzini F, Iasevoli F, Squillace M, Guerri G, Napolitano F, Angrisano T, Di Maio A, Keller S, Vitucci D, Galbusera A, Chiariotti L, Bertolino A, de Bartolomeis A, Salvatore F, Gozzi A, Usiello A (2015b) A role for D-aspartate oxidase in schizophrenia and in schizophrenia-related symptoms induced by phencyclidine in mice. Transl Psychiatry 5:e512. CrossRef Medline

Gavin DP, Chase KA, Sharma RP (2013) Active DNA demethylation in postmitotic neurons: a reason for optimism. Neuropharmacology 75 : 233-245. CrossRef Medline

Guida F, Luongo L, Marmo F, Romano R, Iannotta M, Napolitano F, Belardo C, Marabese I, D'Aniello A, De Gregorio D, Rossi F, Piscitelli F, Lattanzi R, de Bartolomeis A, Usiello A, Di Marzo V, de Novellis V, Maione S (2015) Palmitoylethanolamide reduces pain-related behaviors and restores glutamatergic synapses homeostasis in the medial prefrontal cortex of neuropathic mice. Mol Brain 8:47. CrossRef Medline

Han H, Miyoshi Y, Koga R, Mita M, Konno R, Hamase K (2015) Changes in $\mathrm{D}$-aspartic acid and D-glutamic acid levels in the tissues and physiological fluids of mice with various d-aspartate oxidase activities. J Pharm Biomed Anal 116:47-52. CrossRef Medline

Hardingham GE, Bading H (2010) Synaptic versus extrasynaptic NMDA receptor signalling: implications for neurodegenerative disorders. Nat Rev Neurosci 11:682-696. CrossRef Medline

Hashimoto A, Kumashiro S, Nishikawa T, Oka T, Takahashi K, Mito T, 
Takashima S, Doi N, Mizutani Y, Yamazaki T (1993) Embryonic development and postnatal changes in free D-aspartate and D-serine in the human prefrontal cortex. J Neurochem 61:348-351. CrossRef Medline

Hashimoto A, Oka T, Nishikawa T (1995) Anatomical distribution and postnatal changes in endogenous free $\mathrm{D}$-aspartate and $\mathrm{D}$-serine in rat brain and periphery. Eur J Neurosci 7:1657-1663. CrossRef Medline

Heresco-Levy U, Javitt DC, Ebstein R, Vass A, Lichtenberg P, Bar G, Catinari S, Ermilov M (2005) D-Serine efficacy as add-on pharmacotherapy to risperidone and olanzapine for treatment-refractory schizophrenia. Biol Psychiatry 57:577-585. CrossRef Medline

Huang AS, Beigneux A, Weil ZM, Kim PM, Molliver ME, Blackshaw S, Nelson RJ, Young SG, Snyder SH (2006) D-Aspartate regulates melanocortin formation and function: behavioral alterations in D-aspartate oxidasedeficient mice. J Neurosci 26:2814-2819. CrossRef Medline

Kantrowitz JT, Malhotra AK, Cornblatt B, Silipo G, Balla A, Suckow RF, D'Souza C, Saksa J, Woods SW, Javitt DC (2010) High dose D-serine in the treatment of schizophrenia. Schizophr Res 121:125-130. CrossRef Medline

Katane M, Kawata T, Nakayama K, Saitoh Y, Kaneko Y, Matsuda S, Saitoh Y, Miyamoto T, Sekine M, Homma H (2015a) Characterization of the enzymatic and structural properties of human D-aspartate oxidase and comparison with those of the rat and mouse enzymes. Biol Pharm Bull 38: 298-305. CrossRef Medline

Katane M, Yamada S, Kawaguchi G, Chinen M, Matsumura M, Ando T, Doi I, Nakayama K, Kaneko Y, Matsuda S, Saitoh Y, Miyamoto T, Sekine M, Yamaotsu N, Hirono S, Homma H (2015b) Identification of novel D-aspartate oxidase inhibitors by in silico screening and their functional and structural characterization in vitro. J Med Chem 58:7328-7340. CrossRef Medline

Krashia P, Ledonne A, Nobili A, Cordella A, Errico F, Usiello A, D'Amelio M, Mercuri NB, Guatteo E, Carunchio I (2015) Persistent elevation of D-aspartate enhances NMDA receptor-mediated responses in mouse substantia nigra pars compacta dopamine neurons. Neuropharmacology 103:69-78. CrossRef Medline

Krebs HA (1935) Metabolism of amino-acids: deamination of amino-acids. Biochem J 29:1620-1644. CrossRef Medline

Lane HY, Chang YC, Liu YC, Chiu CC, Tsai GE (2005) Sarcosine or D-serine add-on treatment for acute exacerbation of schizophrenia: a randomized, double-blind, placebo-controlled study. Arch Gen Psychiatry 62:1196-1204. CrossRef Medline

Lipton SA (2008) NMDA receptor activity regulates transcription of antioxidant pathways. Nat Neurosci 11:381-382. CrossRef Medline

Malthe-Sørenssen D, Skrede KK, Fonnum F (1979) Calcium-dependent release of D- $\left[{ }^{3} \mathrm{H}\right]$ aspartate evoked by selective electrical stimulation of excitatory afferent fibres to hippocampal pyramidal cells in vitro. Neuroscience 4:1255-1263. CrossRef Medline

Marutha Ravindran CR, Ticku MK (2005) Role of CpG islands in the upregulation of NMDA receptor NR2B gene expression following chronic ethanol treatment of cultured cortical neurons of mice. Neurochem Int 46:313-327. CrossRef Medline

Migliarini S, Pacini G, Pelosi B, Lunardi G, Pasqualetti M (2013) Lack of brain serotonin affects postnatal development and serotonergic neuronal circuitry formation. Mol Psychiatry 18:1106-1118. CrossRef Medline

Nakatsuka S, Hayashi M, Muroyama A, Otsuka M, Kozaki S, Yamada H, Moriyama Y (2001) D-Aspartate is stored in secretory granules and released through a $\mathrm{Ca}(2+)$-dependent pathway in a subset of rat pheochromocytoma PC12 cells. J Biol Chem 276:26589-26596. CrossRef Medline

Negri A, Tedeschi G, Ceciliani F, Ronchi S (1999) Purification of beef kidney D-aspartate oxidase overexpressed in Escherichia coli and characterization of its redox potentials and oxidative activity towards agonists and antagonists of excitatory amino acid receptors. Biochim Biophys Acta 1431:212-222. CrossRef Medline

Neidle A, Dunlop DS (1990) Developmental changes in free D-aspartic acid in the chicken embryo and in the neonatal rat. Life Sci 46:1517-1522. CrossRef Medline

Nelson ED, Kavalali ET, Monteggia LM (2008) Activity-dependent sup- pression of miniature neurotransmission through the regulation of DNA methylation. J Neurosci 28:395-406. CrossRef Medline

Palacín M, Estévez R, Bertran J, Zorzano A (1998) Molecular biology of mammalian plasma membrane amino acid transporters. Physiol Rev 78: 969-1054. Medline

Parsons MP, Raymond LA (2014) Extrasynaptic NMDA receptor involvement in central nervous system disorders. Neuron 82:279-293. CrossRef Medline

Raiteri L, Zappettini S, Milanese M, Fedele E, Raiteri M, Bonanno G (2007) Mechanisms of glutamate release elicited in rat cerebrocortical nerve endings by 'pathologically' elevated extraterminal $\mathrm{K}^{+}$concentrations. J Neurochem 103:952-961. CrossRef Medline

Riga D, Riga S, Halalau F, Schneider F (2006) Brain lipopigment accumulation in normal and pathological aging. Ann N Y Acad Sci 1067:158-163. CrossRef Medline

Sacchi S, Lorenzi S, Molla G, Pilone MS, Rossetti C, Pollegioni L (2002) Engineering the substrate specificity of D-amino-acid oxidase. J Biol Chem 277:27510-27516. CrossRef Medline

Sakai K, Homma H, Lee JA, Fukushima T, Santa T, Tashiro K, Iwatsubo T, Imai K (1998) Emergence of D-aspartic acid in the differentiating neurons of the rat central nervous system. Brain Res 808:65-71. CrossRef Medline

Savage DD, Galindo R, Queen SA, Paxton LL, Allan AM (2001) Characterization of electrically evoked $\left[{ }^{3} \mathrm{H}\right]$-D-aspartate release from hippocampal slices. Neurochem Int 38:255-267. CrossRef Medline

Schell MJ, Cooper OB, Snyder SH (1997) D-aspartate localizations imply neuronal and neuroendocrine roles. Proc Natl Acad Sci U S A 94:20132018. CrossRef Medline

Setoyama C, Miura R (1997) Structural and functional characterization of the human brain D-aspartate oxidase. J Biochem 121:798-803. CrossRef Medline

Shalini S, Dorstyn L, Dawar S, Kumar S (2015) Old, new and emerging functions of caspases. Cell Death Differ 22:526-539. CrossRef Medline

Sisalli MJ, Secondo A, Esposito A, Valsecchi V, Savoia C, Di Renzo GF, Annunziato L, Scorziello A (2014) Endoplasmic reticulum refilling and mitochondrial calcium extrusion promoted in neurons by NCX1 and NCX3 in ischemic preconditioning are determinant for neuroprotection. Cell Death Differ 21:1142-1149. CrossRef Medline

Still JL, Buell MV (1949) Studies on the cyclophorase system: D-aspartic oxidase. J Biol Chem 179:831-837. Medline

Streit WJ, Xue QS (2014) Human CNS immune senescence and neurodegeneration. Curr Opin Immunol 29:93-96. CrossRef Medline

Streit WJ, Braak H, Xue QS, Bechmann I (2009) Dystrophic (senescent) rather than activated microglial cells are associated with tau pathology and likely precede neurodegeneration in Alzheimer's disease. Acta Neuropathol 118:475-485. CrossRef Medline

Streit WJ, Xue QS, Tischer J, Bechmann I (2014) Microglial pathology. Acta Neuropathol Commun 2:142. CrossRef Medline

Topo E, Fisher G, Sorricelli A, Errico F, Usiello A, D’Aniello A (2010) Thyroid hormones and D-aspartic acid, D-aspartate oxidase, D-aspartate racemase, $\mathrm{H}_{2} \mathrm{O}_{2}$, and ROS in rats and mice. Chem Biodivers 7:1467-1478. CrossRef Medline

Tsai G, Yang P, Chung LC, Lange N, Coyle JT (1998) D-Serine added to antipsychotics for the treatment of schizophrenia. Biol Psychiatry 44: 1081-1089. CrossRef Medline

Tsai GE, Yang P, Chang YC, Chong MY (2006) D-Alanine added to antipsychotics for the treatment of schizophrenia. Biol Psychiatry 59:230-234. CrossRef Medline

Van Veldhoven PP, Brees C, Mannaerts GP (1991) D-Aspartate oxidase, a peroxisomal enzyme in liver of rat and man. Biochim Biophys Acta 1073: 203-208. CrossRef Medline

Wolosker H, D'Aniello A, Snyder SH (2000) D-Aspartate disposition in neuronal and endocrine tissues: ontogeny, biosynthesis and release. Neuroscience 100:183-189. CrossRef Medline

Zaar K, Köst HP, Schad A, Volkl A, Baumgart E, Fahimi HD (2002) Cellular and subcellular distribution of D-aspartate oxidase in human and rat brain. J Comp Neurol 450:272-282. CrossRef Medline 